\title{
Identifying student and classroom characteristics related to primary school students' listening skills: A systematic review
}

\author{
Bourdeaud'hui Heleen $^{\mathrm{a}}$, Aesaert Koen ${ }^{\mathrm{a}}$, Van Keer Hilde ${ }^{\mathrm{a}}$, Johan van Braak ${ }^{\mathrm{a}}$
}

aDepartment of Educational Studies, Ghent University, Ghent, Belgium

\begin{abstract}
This study presents a systematic review of the empirical research on primary school students' first language listening skills. In total, 27 studies were selected and reviewed. The purpose of this review is twofold. First, outcome variables of listening skills were labeled according to the conceptual HURIER model of Brownell (2006). Results showed that most studies evaluated listening skills as the ability to remember, understand or interpret the auditory message. Second, important correlates according to the model of Palardy and Rumberger (2008) were related to primary school students' listening skills. At the classroom level, a significant relationship was found between students' listening skills and teaching practices (e.g. listening strategy instruction) as well as classroom features (e.g. classroom noise). At the student level, a significant relationship was found between students' listening skills and their cognitive skills (e.g. working memory) and background characteristics (e.g. socioeconomic status). Based on these results, suggestions for further research and practice are discussed.
\end{abstract}

Key words: listening skills, primary education, language education, educational effectiveness, systematic review

\section{Highlights}

- This systematic literature review reveals trends and shortcomings in empirical studies regarding listening skills in the primary education context.

- The HURIER model of Brownell (2006) is used as a conceptual framework.

- The model of Palardy and Rumberger (2008) is used as an analytical framework.

- Input and process characteristics of listening skills at the student and class level are identified. 
This systematic review is relevant as it illustrates how listening skills, defined by the HURIER model of Brownell (2006), could be improved by identifying different important correlates of first language listening skills according to the model of Palardy and Rumberger (2008).

\section{Introduction}

Listening is one of the four language skills, next to speaking, reading and writing (Hopper, 2007). Good listening skills are of critical importance in daily, relational, educational and industrial life (Iwankovitsch, 2001). In the educational context, research indicates that primary school students spend approximately 50 to $75 \%$ of each school day listening to teachers, classmates or audio-supported media (Imhof, 2008; Sandall, Schramm, \& Seibert, 2003). Consequently, proficient listening is an essential language skill for primary school students, for various reasons (Barr, Dittmar, Roberts, \& Sheraden, 2002; Bommelje, Houston, \& Smither, 2003; Dickinson, McCabe, \& Sprague, 2003). First, listening skills and academic success or knowledge are closely connected, since listening is an important medium for students to process and acquire information (Sandall et al., 2003). More specifically, students require listening skills because it is the primary means by which information is transferred from teachers to students. If students listen efficiently, they are able to follow a line of reasoning, monitor their understanding and actively connect new information to their prior knowledge (Imhof, 2008; Wolvin \& Coakley, 2000). The second reason why listening skills are essential in primary school is that they play a key role in literacy success and the development of numerous other language skills, such as reading comprehension (e.g. Jalongo, 2008) and writing skills (e.g. Sandall et al. 2003). Third, students also need listening skills to understand practical oral instructions from the teacher, such as homework assignments (Owca, Pawlak \& Pronobis, 2003). Finally, good listening skills are fundamental for the development of social and relational skills in the school context (e.g. during group discussions, literary conversations) (Adelmann, 2012; Wolvin \& Coakley, 2000).

Despite its importance, listening skills are still rather challenging for many students (Owca et al., 2003), especially for non-native speakers (Janusik, 2010; Swanson, 1997) and students with language impairments (Hulme \& Snowling, 2009), learning disabilities (Pulsifer, 1996) or hyperactivity disorders (McInnes, Humphries, Hogg-Johnson \& Tannock, 2003). There are many different explanations why so many students with normal hearing capacity also possess insufficient first language listening skills. In the literature, various contextual factors have been mentioned, such as classroom noise and bad acoustics (Dockrell \& Shield, 2006; 
Howard, Munro \& Plack, 2010). It has also been suggested that there is a shortage of listening instruction (Beall, Rosier-Gill, Tate \& Matten, 2008; Hopper, 2007; Johnson \& Long, 2007). In communication courses, in particular, less than $7 \%$ of the time is actually spent on providing listening instruction (Janusik, 2002; Janusik \& Wolvin, 2002). A possible explanation for this lack of listening instruction is the fact that there is simply not enough high-quality material to teach listening skills (Jalongo, 1996; Janusik, 2002). In this respect, it is often argued that listening has long been regarded as a passive and instinctive skill that develops naturally, resulting in little instruction time dedicated to teaching it (Jalongo, 1996; Swanson, 1997). More recently, language researchers see listening as a complex mental process that does not develop spontaneously but requires instruction (Adelmann, 2012; Beall et al., 2008; Kutlu \& Aslanoğlu, 2009). During the last two decades, language researchers increasingly focus on listening research. Predictors of listening skills are being more and more investigated in (pre)school students (e.g. Florit, Roch, \& Levorato, 2011; 2013) and second language learners (e.g. Li, Cheng, \& Kirby, 2012). In the primary school context, listening researchers often relate student background characteristics such as gender and home language to listening skills (e.g. Yildiz et al., 2010). Other language researchers identify linguistic knowledge (e.g. vocabulary) and cognitive abilities (e.g. working memory or reasoning skills) as the most important predictors of listening skills (e.g. Wolfgramm, Suter \& Göksel, 2016). Further, they increasingly investigate the effect of teachers' instructional methods on listening skills (e.g. Oduolowu \& Oluwakemi, 2014; Stevens, Van Meter \& Warcholak, 2016). Despite the newly found accreditation of listening and the availability of recent experimental listening studies, there is, however, no state-of-the-art of what works in listening education. In general, the findings of existing listening studies have not yet been synthesized and an overview of the empirical listening research in primary school is lacking (Wolfgramm et al., 2016). As a consequence, listening skills still remain one of the least understood processes in language acquisition (Osada, 2004). Therefore, the intent of this study is to analyze the existing listening literature and to give a systematic overview of the correlates of primary school students' listening skills. An overview of the existing knowledge about listening skills is essential to enlarge the knowledge about listening skills, predictors of listening skills and the evidence-informed teaching of listening skills.

In addition, there is still no universally accepted view regarding the conceptualization of listening. This lack of agreement about fundamental concepts has made it difficult to identify the boundaries of the field for purposes of teaching and research (Witkin \& Trochim, 1997). As a consequence, there is considerable variability in defining and especially in evaluating 
listening skills. For instance, some researchers assessed listening in a quantitative manner by using a multiple-choice listening test (e.g. Aarnoutse, van den Bos, \& Brand-Gruwel, 1998), while others evaluated listening during an interactive moment between the students and the teacher (e.g. Oduolowu \& Oluwakemi, 2014). In this way, the first challenge of this review is to organize the different listening concepts in the literature. In this respect, a conceptual model will be used to describe and analyze the outcome variables of students' listening skills in different studies. The second challenge is to give a systematic overview of which student, classroom and school variables are related to primary school students' listening skills. An educational effectiveness model will be used as a framework to categorize the selected listening studies.

\section{Theoretical framework}

\subsection{Defining listening skills: the HURIER model}

Many different definitions of first language listening skills are found in the literature (McKenzie \& Clark, 1995; Witkin, 1990). Most of these definition models share similar components and almost all are consistent with variations of the six most used elements in listening definitions: i.e. perception, attention, remembering, interpreting, evaluating and responding (Janusik, 2007). For example, Wolvin and Coakley's behavioral model defines listening as 'the process of receiving, attending to and assigning meaning to aural and visual stimuli' (Wolvin \& Coakley, 1996, p.69). Barker conceptualizes listening as 'the selective process of attending to, hearing, understanding, and remembering aural symbols' (Barker, 1971, p.17), while Bostrom defines listening rather as the acquisition, processing, and retention of information in the interpersonal context' (Bostrom, 1997, p. 247). In addition, Brownell (2012) fragmented listening into a range of skills and developed the HURIER model, which is an acronym for hearing, understanding, remembering, interpreting, evaluating and responding. Brownell's HURIER model resulted from a comprehensive review of the literature and standardized tests to measure listening competence.

For the purpose of this review, the model of Brownell (2012) was chosen to define listening skills, as this model provides the clearest and most complete blueprint for listening development and testing. Moreover, the HURIER model recognizes the complexity of listening and clearly defines the six behaviors involved in the listening process. As a consequence, Brownell's six proficiency levels are suitable to investigate different aspects of students' 
listening skills. Although these six components are interrelated, each component can be approached as a separate skill area (Brownell, 2012).

The first component, hearing, is a physiological and passive process, referred to as the ability to attend to and perceive a message (Brownell, 2012; Sweetow \& Sabes, 2006). The ability to hear presupposes a healthy, functioning auditory system and is a prerequisite for listening (Behrens, 2010).

Next, understanding is an active process that allows listeners to comprehend the message based on information literally presented. Understanding implies that the listener decodes and analyzes the message to comprehend it (Brownell, 2012). Students constantly find themselves in listening situations where understanding is their primary goal, for example when they are looking for details in an auditory text or are following directions from teachers and peers (Brownell, 1994).

The third component, remembering, is the ability to retain and retrieve information in working and long-term memory. Early memory researchers divided the memory process of listening into short-term and long-term memory (e.g. Kahneman, 1973; Loftus \& Loftus, 1976). By 1980, the Working Memory theory became the dominant theoretical perspective, replacing short-term memory theory (Janusik, 2007). Working memory, often described as a "mental workspace", refers to the ability to actively keep task-relevant information in mind while processing information (Just \& Carpenter, 1992). While working memory has a limited storage capacity (Janusik, 2007), the opposite is true for long-term memory (Brownell, 2006). Longterm memory has an enormous storage capacity, as it requires the retrieval of information that is no longer present or maintained in an active state (Cowan, 2008). Both working and longterm memory are key cognitive resources associated with individual differences in listening skills (Just \& Carpenter, 1992).

The fourth component of the HURIER model is interpreting, which refers to the ability to combine visual, auditory and situational information to fully understand a message. Moreover, interpreting refers to attaching meaning by connecting information from the text to previous experiences (Brownell, 2012). Interpreting also means making sense of a message by processing paralinguistic (e.g. tone of voice), kinesthetic (e.g. posture, facial expression, bodily movement) and proxemics cues (e.g. contextual knowledge, the use of space) (Brownell, 2006; 2012; Wolvin, 2010). In this respect, audiovisual listening material is superior to audio only material, since the dual-channel representation provides more information for students to interpret the message (Mayer, 2001). 
Fifth, evaluating entails the ability to assess a message, referred to as critical listening by Brownell (2012). Critical listeners apply a variety of skills, such as judging the validity and adequacy of main ideas and supporting arguments, distinguishing facts from opinions, inspecting, comparing and contrasting ideas, and arriving at a conclusion.

The final component, responding, is being able to select an appropriate response to what is heard. As to the classroom context, researchers prefer the term interactive listening rather than responding (Canpolat, Kuzu, Yildirim, \& Canpolat, 2015; Vandergrift, 1997). Interactive listening takes place in a communicative situation in which the listener, taking an active role, provides responses, such as signaling comprehension, requesting clarification and negotiating meanings. In doing so, s/he solves communication problems, shapes the discourse, and accomplishes certain goals of interaction (Xiaoxian \& Yan, 2010). Based on these six components of the HURIER model, the present study defines listening as an interactive and comprehension process through which students hear, understand, remember, interpret, evaluate and respond to what is presented.

\subsection{Analyzing listening skills according to the effectiveness model of Palardy and Rumberger (2008)}

The major aim of educational effectiveness models is to reveal the impact of relevant input and process characteristics on educational outputs and this at the student, classroom and school level (Scheerens, 2016). For this review, an educational effectiveness model will be used as an analytical framework to determine which characteristics are associated with differences in students' listening skills. The field of educational effectiveness research offers some welldeveloped and research-based theoretical models such as the dynamic model of Creemers and Kyriakides (2010), the model of Palardy and Rumberger (2008) or the model developed by Scheerens (1992). These educational effectiveness models all systematically present inputs and processes related to educational outcomes and explain why specific factors are important for explaining variation in student outcomes. In order to choose the best fitting analytical framework for this systematic review, different effectiveness models were compared. Eventually, the model of Palardy and Rumberger was selected because this model subdivides general categories (e.g. teacher practice or student background) in very specific and thoroughly described subcategories (e.g. "instructional modalities of the teacher" or "family background") and this for the student, class and school level. This subdivision facilitates the categorization of selected studies according to the different levels of the model. 
The model of Palardy and Rumberger (2008) (Fig. 1) illustrates that educational input and process characteristics operate at three levels to explain the variation in students' achievement, i.e. the student, classroom and school level. Input characteristics refer to the structural, contextual and background characteristics of the students, teachers and schools that are potentially related to students' outcomes but are beyond their control. Process characteristics, in contrast, refer to behavioral and attitudinal characteristics over which students, teachers and schools have more control (Palardy \& Rumberger, 2008).

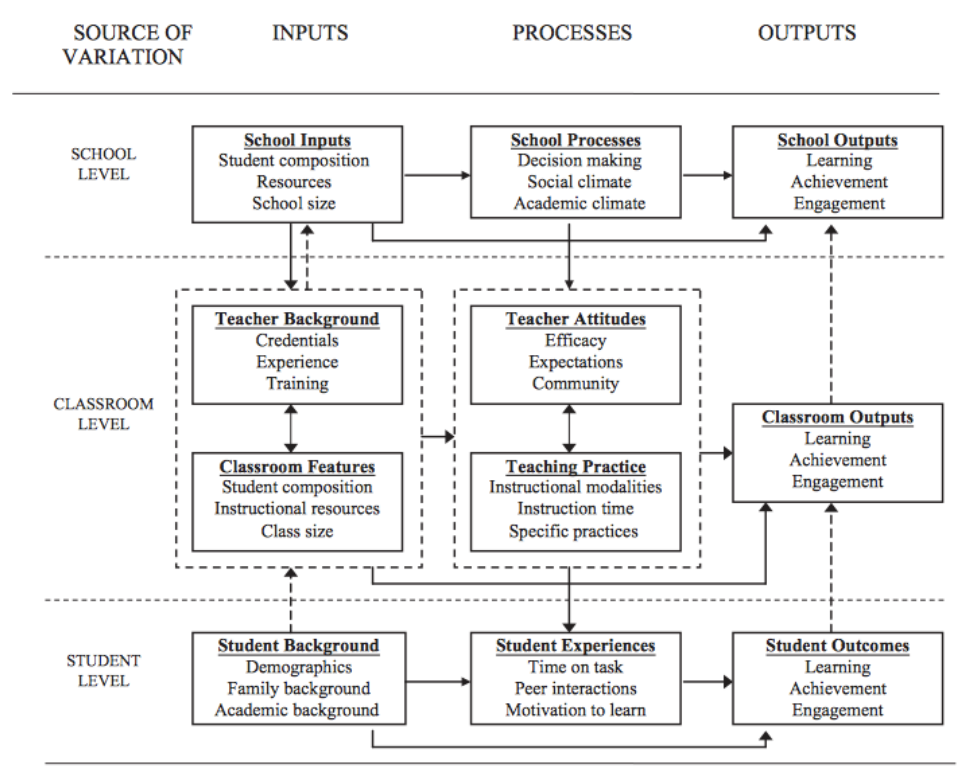

Fig. 1. The educational effectiveness model of Palardy and Rumberger (2008)

The first level at which these characteristics operate involves the student level. Student input characteristics are classified into three categories: demographics (subcategories: ethnicity, age and gender), family background characteristics (subcategories: socioeconomic status and family structure) and academic background characteristics (subcategories: prior achievement and retention). Palardy and Rumberger (2008) refer to student process characteristics as student experiences, which include time on task, peer interactions and motivation to learn.

The second level at which these characteristics operate involves the classroom level. In the model of Palardy and Rumberger (2008) this level refers to both classroom and teacher characteristics. Classroom input characteristics refer to teacher background (subcategories: credentials, experience and training) and classroom features (subcategories: class composition, instructional resources and class size). Further, Palardy and Rumberger (2008) define classroom processes as (1) teacher attitudes (subcategories: teacher expectations, community and teacher efficacy) and (2) teacher practices (subcategories: instruction time, instructional 
modalities and specific practices). More specifically, the subcategory "instructional modalities" refers to a general teaching technique such as ability grouping or differentiation, while "specific practices" entail subject-specific listening activities such as providing instruction on listening strategies or using a specific type of auditory text (Palardy \& Rumberger, 2008).

At the third level, school input characteristics involve student composition (e.g. based on socioeconomic background), resources (e.g. type of textbooks) and school size. School process characteristics include decision-making and the school's academic and social climate (Palardy \& Rumberger, 2008).

To conclude, the general aim of this review is to synthesize existing listening research and to foster the development of new knowledge concerning listening skills, predictors of listening skills and the evidence-informed teaching of listening skills. To reach this goal, we first want to investigate how students' listening skills were defined and described in different studies, according to the HURIER model. Second, we want to investigate which input and process characteristics according to the model of Palardy and Rumberger (2008) are related to primary school students' listening skills. In this way, the general aim can be subdivided into two research objectives:

(RO1): Identifying skills of Brownell's HURIER model (2006) addressed in the listening research literature;

(RO2): Categorizing the input and process characteristics of the listening studies according to the model of Palardy and Rumberger (2008).

\section{Method}

To analyze which input and process characteristics at the student, class and school level are related to primary school students' listening skills, the standard steps of a systematic review process were followed. First, potential studies were searched through scanning relevant databases. Second, these potential studies were screened and selected on the basis of inclusion and exclusion criteria, based on the recommendations of the PRISMA statement. Third, the data from the selected studies were abstracted and analyzed. All steps of the review process were discussed in an interdisciplinary research team consisting of two educational effectiveness researchers and one literacy researcher. 


\subsection{Literature search}

To conduct this review, the major electronic and academic databases - The Education Resources Information Center (ERIC), Web of Science (WoS) and Linguistics and Language Behavior Abstracts (LLBA) - were searched for scholarly journal articles in December 2017. The search was limited to the last three decades before the study began. A Boolean logic combining key concepts from the research question was applied. Search strings consisted of a combination of the following terms that were scanned for in titles, keywords, abstracts and full text: (listening * OR listening skills OR listening comprehension) AND (correlates OR predictors) NOT (second language OR foreign language OR EFL OR ESL). Only peerreviewed studies were identified, resulting in 3553 hits.

\subsection{Study selection}

The study selection protocol is based on the recommendations of the Preferred Reporting Item for Systematic reviews and Meta-Analyses PRISMA statement (Moher, Liberati, Tetzlaff, \& Altman, 2010). The PRISMA flow diagram (Fig. 2) conveys the different phases of this systematic review from the number of records identified through to those included and excluded. 


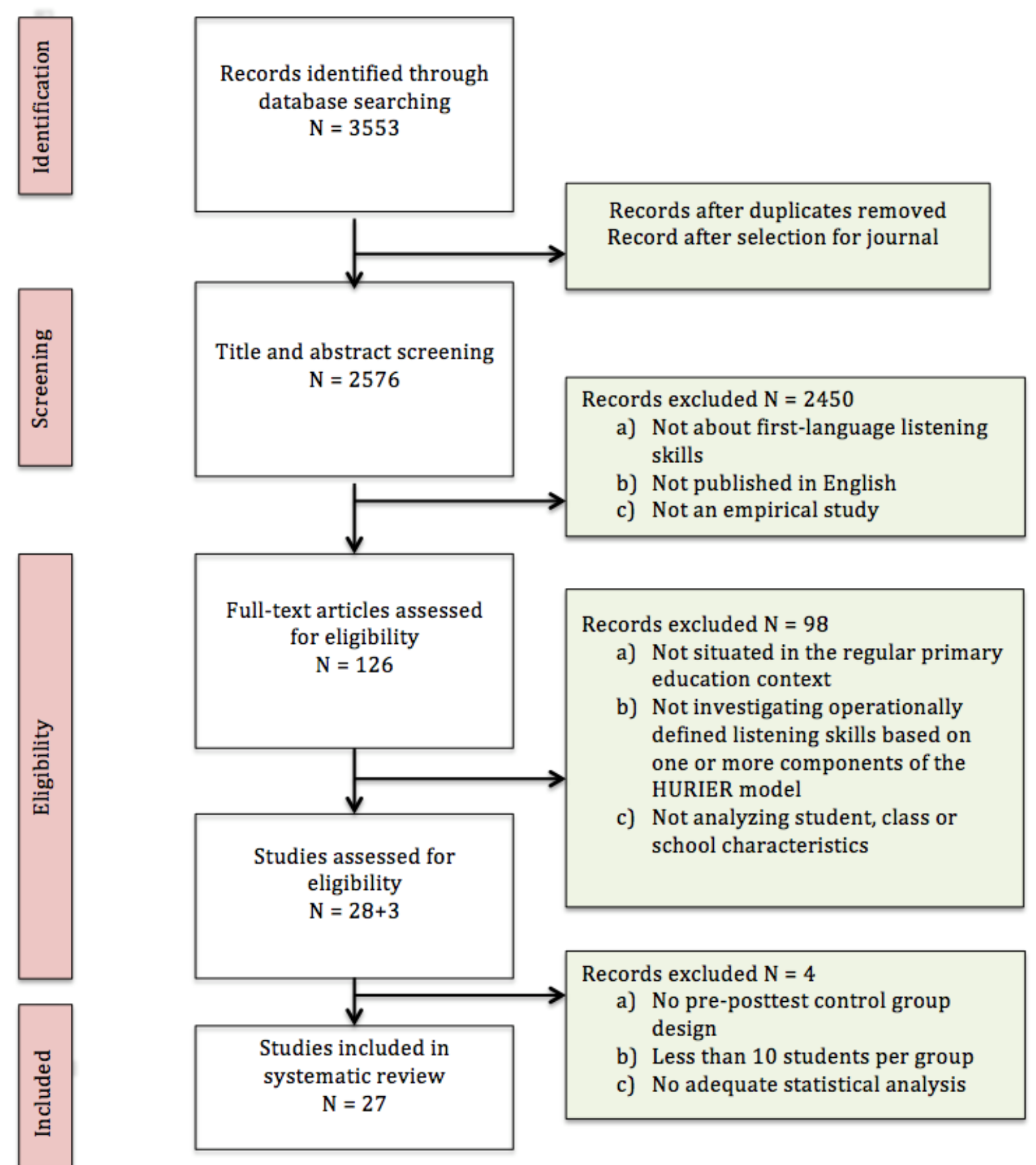

Fig. 2. Overview of the search protocol based on the PRISMA statement.

The initial search of the three databases identified 3553 studies. Duplicates were excluded and results were refined by research domain (i.e. social sciences, educational research and psychology), resulting in 2756 studies. In the first screening phase, the first author screened relevant studies by judging title and abstract. Studies were excluded if they were not about first-language listening skills, were not published in English or were not reporting an empirical study (e.g. reviews or editorial). After this first screening phase, the remaining 126 studies were downloaded to a computer into the electronic format Mendeley. These studies were read fully 
in order to evaluate their relevancy for the aims of this study. Again, these studies were screened against different inclusion and exclusion criteria. In this second selection phase, studies were excluded if (a) the study was not situated in the regular primary education context. More specifically, studies were excluded if they focused on second- or foreign-language listening skills or focused on listening in music education. Further, studies were excluded if (b) the study was not investigating operationally defined listening skills based on one or more components of the HURIER model or (c) the study was not analyzing the relationship between student, class or school characteristics and students' listening skills.

Based on these eligibility criteria, the first author selected 28 relevant studies. Three extra studies were selected after scanning the reference lists of the full text papers (snowballing method). After fully-reading the articles, 31 studies were selected. In case of doubt, the members of the interdisciplinary team assessed the relevance of these studies. In order to select interventional and correlational studies of sufficient quality, different methodological criteria for the interventional and correlational studies were considered. The following three methodological criteria were considered for the interventional studies:

- The interventional study had to include a control group. Without control group it is unclear whether the results of the experimental group were caused by the intervention or by normal developments.

- The interventional study had to provide pretest and posttest measures. If there was no pretest, there could be initial differences between the control and the experimental group.

- The study sample had to include at least ten students per group in order to ensure that the effect size Cohen's $d$ would be approximately normally distributed (Hedges \& Olkin, 1985). Studies with fewer than ten students per group were, therefore, excluded from our systematic review.

The following methodological criteria was considered for the correlational studies:

- The correlational study had to include adequate statistical analysis with significance level/confidence intervals reported.

To maintain a high methodological quality, four extra interventional studies that did not meet our methodological criteria were deleted. The final literature search yielded 27 studies that were analyzed in the review. Of the selected studies, 14 studies were interventional studies and 13 were cross-sectional studies.

\subsection{Data abstraction and analysis}


In the first phase of analysis, the following study characteristics were formally abstracted: authors and publication year, country, grade and sample size, methodology, study design, study duration, level and description of the independent and dependent variables, applied listening test, and study outcomes. The descriptive information of the papers can be found in Appendix A, B, C and D. During the second phase of analysis, the first author clustered the 27 selected studies. First, the dependent variables were categorized according to the six components of the HURIER model of Brownell (2006). Second, the independent variables were categorized according to the category (e.g. student background) and the subcategory (e.g. family background) of the multilevel model of Palardy and Rumberger (2008). In a third phase of analysis, an independent coder reviewed the categorization of all 27 studies based on the abstracts. When this categorization was compared to that of the first author, it was shown that all disagreement was due to ambiguity in the subcategories of instructional modalities and specific practices. These subcategories were therefore further clarified and categorized once more by both the first author and the independent coder. Afterwards, a percent agreement for the categorization of all 27 studies of $100 \%$ was achieved for the subdivision in levels, $96 \%$ for the subdivision in categories and 93\% for the subdivision in subcategories. In case of disagreement, consensus was reached between the reviewers by discussion. In a fourth phase, for each category and subcategory of the model of Palardy and Rumberger (2008), all relevant findings were described to make comparisons and render joint interpretations. In the final analysis stage, the findings were summarized and conclusions were drawn to present an overview of the relationship between input and process characteristics on the one hand and students' listening skills on the other hand.

\section{Results}

In total, this review included 27 studies. This section presents the findings from the systematic review based on the HURIER model (2006) and the model of Palardy and Rumberger (2008).

\subsection{Identifying skills of Brownell's HURIER model (2006) addressed in the listening research literature}

The six components of the HURIER model (i.e. Hearing, Understanding, Remembering, Interpreting, Evaluating and Responding) were used to label the outcome variables (i.e. listening skills) of the selected studies. Table 1 shows that all 27 studies evaluated maximum three different components of the HURIER model. Most studies could be classified on the 
understanding (18 studies) and/or interpreting level (12 studies) of the HURIER model (Brownell, 2012). This means that most studies evaluated listening skills as the capacity to identify information that has been explicitly mentioned in the text (i.e. understanding level) or as the capacity to integrate different information from the text (i.e. interpreting level). For example, in the study of Paris and Paris (2016) teachers taught their students different strategies to identify story characters and objects (understanding component) or to make inferences about thoughts and feelings (interpreting component). Further, 8 studies focused on the remembering level. In these studies students often have to retell a story or have to recall as many events as they could remember. For example, in the study of Stevens et al. (2016) teachers trained their students in retelling narrative stories. Only 5 studies included the hearing level. These studies mainly investigated in which listening condition (e.g. listening to a story with or without background noise) students show the most favorable listening behavior. Finally, only 4 of the 27 studies focused on the evaluating level (e.g. students have to make judgments about the content of the text) and 2 studies focused on the responding level (e.g. students need to compose a poem about a story). A detailed overview indicating how outcome variables were labeled according to the HURIER model is in Appendix A (teaching practice), Appendix B (classroom features), Appendix C (teacher background) and Appendix D (student background).

Table 1

Overview of studies per level of the HURIER model

\begin{tabular}{lll}
\hline Level of the HURIER model & Studies & $\begin{array}{l}\text { Number of } \\
\text { studies }\end{array}$ \\
\hline Hearing & $2,12,13,14,16$ & 5 \\
Understanding & $1,4,5,8,9,10,15,16,17,18,19,20,21,23,24,25,26,27$ & 18 \\
Remembering & $6,7,8,10,16,22,24,25$ & 8 \\
Interpreting & $1,3,5,8,9,11,15,17,20,21,24,27$ & 12 \\
Evaluating & $4,20,21,23$ & 4 \\
Responding & 3,11 & 2
\end{tabular}

\subsection{Categorizing the input and process characteristics of the listening studies according to the model of Palardy and Rumberger (2008)}

In total, 15 studies focused on the class-level variables and 12 examined student-level variables. No studies were found to address characteristics at the school level. Table 2 gives an overview of the categorization and results of all studies included in the systematic review. Out of the 27 studies, 26 were conducted from a single-level perspective. For these studies, all the independent variables belonged to one level of the model of Palardy and Rumberger (2008), more specifically the student or class level. Only one multilevel study, the study of Oduolowu 
and Oluwakemi (2014) was classified into two different levels (i.e. class level as well as student level). 
Table 2

Overview of studies per level, category and correlate

\begin{tabular}{|c|c|c|c|c|c|}
\hline Level & Category & Subcategory & Correlate & Studies & $\begin{array}{l}\text { Results } \\
\text { Effect size }(d) \text { : small }=0.20, \text { moderate }= \\
0.50, \text { large }=0.80\end{array}$ \\
\hline \multirow[t]{8}{*}{ Class } & \multirow[t]{5}{*}{ Teaching practice } & \multirow[t]{4}{*}{ Specific practices } & Listening strategy instruction & 1 & Significant positive $(\mathrm{p}<.05)$ \\
\hline & & & Text type familiarization techniques & $4,5,8,10$ & $\begin{array}{l}\text { Significant positive: } 5(\mathrm{p}<.001), 8(\mathrm{p}<.05), \mathrm{d}= \\
0.40-0.90,10(\mathrm{p}<.01), \mathrm{d}=0.10-0.49 \\
\text { Non-significant: } 4(\mathrm{p}>.05)\end{array}$ \\
\hline & & & Using specific listening material & 11 & Non-significant $(\mathrm{p}>.05)$ \\
\hline & & & Visual techniques & $3,6,7$ & $\begin{array}{l}\text { Significant positive: } 3(\mathrm{p}<.05), 6(\mathrm{p}<.01), \mathrm{d}= \\
0.80,7(\mathrm{p}<.05), \mathrm{d}=0.73-0.89\end{array}$ \\
\hline & & Instructional modalities & $\begin{array}{l}\text { E.g. Computer-assisted instruction } \\
\text { program, integrating listening and } \\
\text { speaking activities, giving homework }\end{array}$ & 2,9 & $\begin{array}{l}\text { Significant positive: } 2(\mathrm{p}<.01) ; 9 \quad(\mathrm{p}<.001), \\
\mathrm{d}=2.74\end{array}$ \\
\hline & \multirow[t]{2}{*}{ Classroom features } & \multirow[t]{2}{*}{ Classroom features } & Improving classroom acoustics & $12,13,14$ & $\begin{array}{l}\text { Significant positive: } 12(\mathrm{p}<.001), 13(\mathrm{p}<.001), \\
\mathrm{d}=0.90,14(\mathrm{p}<.01)\end{array}$ \\
\hline & & & Class size & 15 & Significant negative $(\mathrm{p}<.05)$ \\
\hline & Teacher background & Teacher background & Teacher training & 16 & Significant positive $(\mathrm{p}<.05)$ \\
\hline \multirow[t]{7}{*}{ Student } & \multirow[t]{6}{*}{ Student background } & \multirow[t]{3}{*}{ Family background } & Socioeconomic status & 17,20 & Significant positive: $17(\mathrm{p}<.01), 20(\mathrm{p}<.001)$ \\
\hline & & & Home language & 26 & Significant positive $(\mathrm{p}<.001), \mathrm{d}=0.48$ \\
\hline & & & Cultural background & 7 & Significant positive $(\mathrm{p}<.001)$ \\
\hline & & \multirow[t]{2}{*}{ Academic background } & Language skills & $17,19,23,26$ & $\begin{array}{l}\text { Significant positive: } 17(\mathrm{p}<.05), 19(\mathrm{p}<.001), \\
23(\mathrm{p}<.01), 26(\mathrm{p}<.001), \mathrm{d}=0.81\end{array}$ \\
\hline & & & Cognitive skills & $18,24,25,26,27$ & $\begin{array}{l}\text { Significant positive: } 18(\mathrm{p}<.001), 24(\mathrm{p}<.05), \\
25(\mathrm{p}<.05), 27(\mathrm{p}<.001), \mathrm{d}=0.46 \\
\text { Non-significant: } 24,26(\mathrm{p}>.05)\end{array}$ \\
\hline & & Demographics & Gender: female & $7,22,23,26$ & $\begin{array}{l}\text { Significant positive: } 7 \quad(\mathrm{p}<.05) \\
\text { Non-significant } 22,23,26 \quad(\mathrm{p}>.05)\end{array}$ \\
\hline & Student experiences & Student experiences & Motivation & 21 & Significant positive $(\mathrm{p}<.001)$ \\
\hline
\end{tabular}


Figure 3 visualizes which categories and correlates of the model of Palardy and Rumberger (2008) could be addressed in this systematic review. This overview shows that most of the studies focused on the relationship between teaching practices (i.e. instructional modalities and specific practices) and student background characteristics (i.e. family background and academic background) on the one hand and students' listening skills on the other hand. At the classroom level, the relationship between classroom features and listening skills was considerably investigated. Further, none of the selected studies addressed teachers' attitudes and only one study addressed teachers' background. At the student level, listening skills related to student experiences were barely investigated. Figure 3 also shows that none of the selected studies focused on the school level.

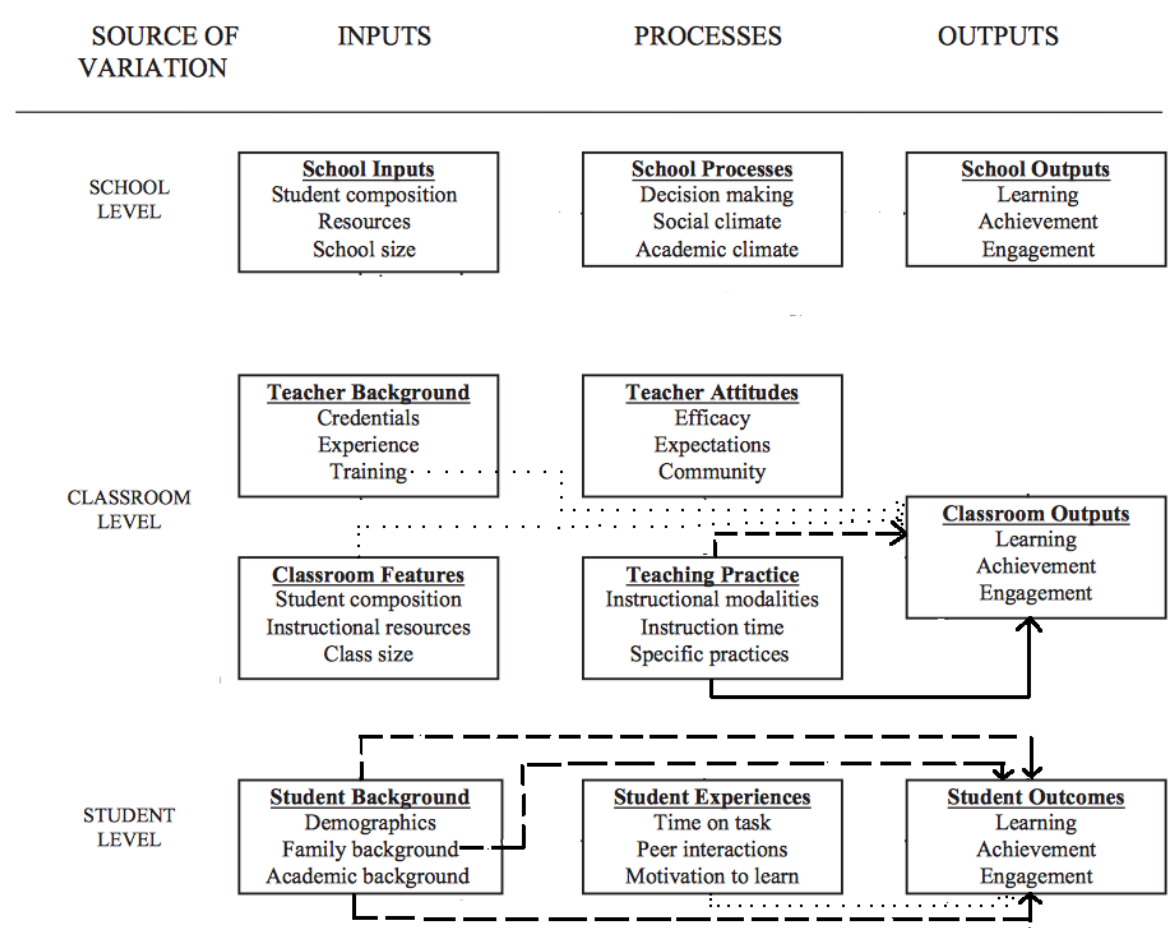

Less than 3 studies investigated this relationship: .....

Between 3 and 10 studies investigated this relationship:

More than 10 studies investigated this relationship:

Fig. 3. Overview of the amount of studies based on the model of Palardy and Rumberger (2008).

\subsubsection{Results at the class level}

Sixteen studies investigated the relationship between class level characteristics and students' listening skills, and 14 of them were intervention studies with a pretest-posttest control group design. The other 2 studies were descriptive in nature, using a cross-sectional design. Of the 14 intervention studies, only 4 studies ${ }^{(1,8,9,16)}$ have included a retention test design. 
As to the class level, three out of four categories (i.e. teaching practice, classroom features and teacher background training) of the model of Palardy and Rumberger (2008) were discussed. A detailed overview indicating how variables at the class level are related to students' listening skills is presented in Appendix A (teaching practice), Appendix B (classroom features) and Appendix C (teacher background).

\subsubsection{Class level: Teaching practice}

This first category at the class level classified 10 intervention studies and 1 crosssectional study investigating the relationship between the practice of the teacher and primary school students' listening skills. Further, teaching practice could be divided into the subcategories "specific practices" $(n=9)$ and "instructional modalities" $(n=2)$. As stated in section 2.2., the subcategory "specific practices" entails subject-specific listening activities such as providing instruction on listening strategies, while the subcategory "instructional modalities" refers to a general teaching technique (Palardy \& Rumberger, 2008). In most studies, a significant positive effect of teaching practice on students' listening skills was observed ( $n=9)$. Most intervention studies about listening skills were set up in the lower primary grades (i.e. first or second grade) with only two studies focusing on upper primary grades (i.e. fifth grade).

Teaching practice: specific practices. Nine studies investigated the relationship between a specific listening practice and students' listening skills. First, four studies ${ }^{(4,5,8,10)}$ examined the effects of specific text type instruction (i.e. instruction in expository or narrative text comprehension) and three out of four found a significant result. In this respect, Paris and Paris (2007) and Stevens et al. (2016) reported a significant positive effect of narrative instruction on narrative listening comprehension, while Kraemer, McCabe and Sinatra (2012) reported a significant positive effect of expository instruction on expository listening comprehension. More specifically, Paris and Paris (2007) found that 83 first-grade students benefited from narrative strategy instruction after a five-week during intervention. Narrative strategy instruction refers to teaching children comprehension strategies that were specific to the cognitive demands of understanding narrative stories. Teachers taught their students, for example, strategies for identifying the characters or making inferences about thoughts and feelings of the stories. Further, in the study of Stevens et al. (2016) kindergarten and first-grade students were trained in narrative text comprehension through story structure instruction (SSI) and this for the period of one school year (15 minutes a day). SSI provides explicit instruction 
during traditional storybook reading. For example, teachers trained students in retelling stories and asked students questions about events such as the main character or the location. In the study of Kraemer et al. (2012) 37 first-grade students heard expository read-alouds for four weeks, while two control classes followed their teacher's normal schedule. Diakidoy (2014), however, found no significant impact of text type familiarization on second-grade students' listening skills.

In addition, three studies ${ }^{(3,6,7)}$ focused on applying visual techniques during listening training and they all reported a significant positive impact on the experimental group. First, Oduolowu and Oluwakemi (2014) found a significant positive effect of storytelling with illustrations on first-grade students' listening skills. During a three-week long intervention, trained teachers told the three stories twice a week. The experimental group was exposed to storytelling supported with illustrations, while the control group did not receive any visual support. After seven weeks the experimental group significantly outperformed the control group in retelling the stories. Second, Center, Freeman, Roberston and Outhred (1999) carried out to assess the effect of a visual imagery training program on the listening skills of 66 secondgrade poor comprehenders, randomly allocated to an experimental group (instruction with visual imagery training) or a control group (instruction without visual imagery). Only the experimental group was asked to visualize (paint a picture in their minds) the main features of each presented object. After 12 listening lessons over four weeks, visualization training appears to significantly improve comprehensive and interpretative listening tasks. Third, Marley and Szabo (2010) examined the cognitive benefits of physical manipulations on 76 kindergarten and first-grade students, randomly assigned to two groups: stories with pictures (viewing pictures of the actors) or manipulation strategy (moving manipulatives as directed by the narrative). Participants were requested to recall as many story events as they could remember. Significant differences in favor of the manipulation strategy were observed.

Furthermore, one study ${ }^{(1)}$ found a significant positive effect of 20 lessons of strategy instruction on the listening skills of 9- to 11-year-old poor readers and listeners. Effective listening strategies were, for example, teaching students to listen for a purpose, clarifying difficult words, imagining the auditory text, predicting what could happen or summarizing the text. Students have to apply these listening strategies while answering questions in a discussion group. The significant results were maintained on retention tests, administered three months after termination of the program.

Finally, only one study ${ }^{(11)}$ investigated the effect of using specific listening material. Tok and Mazi (2015) concluded that an intervention using "stories for thinking” did not reveal 
a significant increase in fifth-grade students' listening skills. Stories for thinking refer to thinking together about the text in discussion groups whereby the researcher acts as a questioner and facilitator.

Teaching practice: instructional modalities. Two studies ${ }^{(2,9)}$ investigated the effect of a general instructional modality and found a significant positive effect in favor of the experimental group. Potocki, Ecalle and Magnan (2012) found notable lasting effects of the use of a computer-assisted program (CAI-program) to remediate listening and reading comprehension difficulties in second-grade students. The CAI-program is a reading and listening training program that distinguishes between two aspects of text comprehension, i.e. literal and inferential comprehension. The difference between the groups was significant at the second post-test, i.e. 11 months after the training phase. Further, Bilican, Kutlu and Yildirim (2012) confirmed in their quantitative correlational study that the combination of listening and reading activities (e.g. giving free reading time or doing homework based on reading passages) is significantly related to fifth-grade grade students' listening skills.

\subsubsection{Class level: Classroom features}

This second category at the class level classified four studies addressing the relationship between classroom features (i.e. classroom noise and class size) and students' listening skills. Further, classroom features could be divided into the subcategories "classroom noise" $(n=3)$ and "class size" $(\mathrm{n}=1)$.

Classroom features: classroom noise. Three studies ${ }^{(12,13,14)}$ reported that attention and listening were impaired when classroom acoustics were less beneficial. Two studies ${ }^{(12,14)}$ indicated the potential benefits of sound field amplification technology for students' listening skills. This technology improves the sound environment of the class by ensuring an even distribution of sound from the teacher, the students and multimedia. Arnold and Canning (1999) and McSporran, Butterworth and Rowson (1997) compared the hearing capacity of students in classes with and without sound field amplification and found a significant positive effect on listening. Good classroom acoustics were especially important for special needs students (e.g. students with learning difficulties, non-native students or students with hearing loss) (McSporran et al., 1997). In addition, Klatte, Lachman and Meis (2010) found a significant negative effect of background speech or background noise on $4^{\text {th }}$ grade students' attention and speech perception.

Classroom features: class size. Only one selected study ${ }^{(15)}$ focused on the relationship 
between class size and students' listening skills. The quantitative study of Shin and Raudenbush (2011) found that reducing class size significantly improves listening scores from kindergarten to third grade.

\subsubsection{Class level: Teacher background}

This third category at the class level classified only one study ${ }^{(16)}$ focusing on the relationship between teacher background characteristics and students' listening skills. Crosskey and Vance (2011) observed significant positive changes in students' listening skills after the implementation of a teacher-training package, including information on the theoretical aspects of the listening material as well as instruction strategies. The teacher-training package presented information about teaching listening skills.

\subsubsection{Results at the student level}

At the student level, eleven studies investigated the relationship between students' listening skills and their background characteristics, while only one study focused on student motivation. There were eleven studies with a cross-sectional design ${ }^{(17,18,19,20,21,22,23,24,25,26,27)}$ and one with a pretest-posttest design ${ }^{(7)}$. A detailed overview of how student background is related to students' listening skills is presented in Appendix D.

\subsubsection{Student background}

In terms of student background, all three subcategories of the model of Palardy and Rumberger (2008) (i.e. family background, academic background and demographics) will be considered below.

Student background: family background. Four correlational studies ${ }^{(7,17,20,26)}$ found a significant positive relationship between family background and students' listening skills. Acat, Demiral and Kaya (2016) found that fifth-grade students' listening skills are positively correlated with the socioeconomic status of the child, measured as the educational level of the mother and the father. Kutlu and Aslanoğlu (2009) found a significant positive relationship with the number of books at home and read within one month. However, no significant relationship was found between the educational level of the mother and students' listening skills. Further, Wolfgramm et al. (2016) found a significant positive relation between sixthgrade students' home language and their listening skills. Students who do not speak the instruction language at home performed significantly worse in listening skills than firstlanguage learners. Oduolowu and Oluwakemi (2014) also found a significant relationship with 
students' home language. They found that students who could listen in their native language performed significantly better.

Student background: academic background. As to students' academic background, seven correlational studies showed that academic background characteristics were positively related to students' listening skills ${ }^{(17,19,23,24,25,26,27)}$. Academic background characteristics can be further subdivided in linguistic knowledge (e.g. vocabulary, language scores) and cognitive skills (e.g. working memory, theory of mind, concentration). With regard to linguistic knowledge, the results of Acat et al. (2016) and Lin et al. (2014) showed a significant positive correlation between general language scores and listening skills. Further, Kim (2016), Kim and Philips (2014) and Wolfgramm et al. (2016) revealed that listening skills are directly predicted by students' vocabulary level. Different studies investigated the relationship between cognitive skills and listening skills. First, Tighe, Spencer and Schatschneider (2015) focused on the influence of working memory, reasoning and fluency on listening skills in third, seventh and tenth grade students. They found that verbal and nonverbal reasoning, word reading fluency, and working memory significantly predicted listening comprehension, but found that working memory was the least predictive. In addition, working memory was only found to be an important predictor to listening skills in the earlier grade levels. Molloy (1997) differentiated between "low-level" and "high-level" working memory tasks, which measure differences in terms of the amount of storage capacity and processing demands placed on the working memory. She found that high-level working memory tasks were more predictive of listening skills than low-level tasks. Only the high-level working memory task was a significant predictor of listening comprehension. However, Wolfgramm et al. (2016) could not actually find a significant relationship between working memory and listening skills. Kim (2016) found that different cognitive skills such as working memory, theory of mind and attention were weakly to moderately related to listening skills. Wolfgramm et al. (2016) and Cain and Bignell (2014) found a significant relationship between concentration and listening skills. Cain and Bignell (2014) found that there was a significant negative effect of high hyperactivity and poor attention on students' listening skills. Finally, Kim and Philips (2014) found that inhibitory control (the ability to suppress a dominant response) was significantly positively related to listening skills. They also revealed that there was a significant relationship between theory of mind (the ability to infer others' mental states), comprehension monitoring (the ability to reflect on and evaluate one's own comprehension of text) and listening skills.

Student background: demographics. Regarding demographics, four correlational studies investigated the relationship between gender and students' listening skills ${ }^{(7,22,23,26)}$. 
However, only the study of Oduolowu and Oluwakemi (2014) found a significant relationship, showing girls performing higher on listening skills than boys. Lehto and Antilla (2003), Lin et al. (2014) and Wolfgramm et al. (2016) could not find a significant relationship between gender and listening skills. Wolfgramm et al. (2016) even found boys performing significantly higher on one of the two listening comprehension tests that were administered.

\subsubsection{Student experiences}

Except for the subcategory "motivation to learn", no studies could be allocated to the other subcategories.

Student experiences: Motivation to learn. The study of Lau (2017) demonstrated that high-proficiency listeners had a significantly higher listening motivation and listening interest in doing listening exercises than low-proficiency listeners. They also found that highproficiency listeners used significantly more listening strategies than low-proficiency listeners.

\section{Discussion}

As stated in the introduction, listening skills are a prerequisite for further educational success. However, to date, there are no literature reviews synthesizing the specific characteristics affecting students' listening skills. Therefore, this study aimed to synthesize the existing listening research by investigating correlates at the student, class and school level related to primary school students' listening skills, as defined in the HURIER model. In this section, we discuss the results of our review and describe the implications for further practice and research.

\subsection{Skills of the HURIER model addressed in the research literature}

The six components of the HURIER model were used to label the outcome variables (i.e. listening skills) of the selected studies. This review showed that the relationship between correlates and listening skills was primarily investigated towards the "lower levels" of listening skills (i.e. remembering, understanding and interpreting level), while the higher levels (i.e. critical or interactive listening) have been barely investigated. We assume the focus on those lower levels is rather a pragmatic decision given higher test complexity and practical constraints when assessing higher order listening skills. In particular, critical or interactive listening skills could be more complex to define and to measure. For example, as interactive listening takes place in a communicative situation in which the listener takes an active role, it is recommended 
to assess interactive listening skills through a face-to-face conversation instead of a classical paper test. As critical and interactive listening skills are barely investigated, future research should focus on the assessment of these higher listening skills.

\subsection{Listening skills and student-level correlates}

This review indicates that different student level characteristics (i.e. academic background, demographics and family background) are correlated to students' listening skills. According to the academic background characteristics of students, especially working memory and vocabulary showed to be significant predictors of listening skills. The strong correlation between working memory and listening skills could be expected, as working memory is necessary to keep task-relevant information in mind while listening (Just \& Carpenter, 1992). However, Wolfgramm et al. (2016) could not find a significant relationship with working memory. The lack of significant results in this study could be attributed to the fact that the listening tests consisted of short auditory texts with simple structures that did not depend on the capacity of the working memory. The correlation between vocabulary and listening skills could also be expected, because lexical gaps may interrupt the continuous process of listening (Hagtvet, 2003).

As to demographics, the results on gender differences are not clear. Most gender studies could not find a significant relationship between gender and listening skills. Only in the study of Oduolowu and Oluwakemi (2014) girls did significantly outperform boys. These results are not in line with research on other language skills, where girls significantly outperform boys in reading comprehension (e.g. Below, Skinner, Fearrington \& Sorrell, 2010; Lynn \& Mikk, 2009) or writing skills (e.g. De Smedt et al., 2017). This difference with other language research was not expected, as it has been suggested that reading and listening rely on similar cognitive processes (e.g. Verlaan, Pearce \& Zeng, 2017).

This review also showed that family background characteristics, such as students' socioeconomic status do relate to students' listening skills (e.g. Acat et al., 2016). A possible explanation for the relationship between SES and students' listening skills is that parents with a higher SES, on general, have the opportunity to provide more supportive conditions for the development of listening skills. For example, they may be more able to interact with clear and responsive communication styles or to use diverse forms of multimedia (Bergen, Zuijen, Bishop, \& Jong, 2017; Sohr-Preston et al., 2013). These results are comparable with other language research, in which SES was shown to be a powerful predictor of students' reading 
(e.g. Bradley \& Corwyn, 2002; Kieffer, 2012) and writing development (e.g. Kim, Puranik \& Otaiba, 2015).

\subsection{Effective instructional practices and implications for listening education}

The identified student-level correlates are generally fixed characteristics that are difficult or impossible to alter in the context of schooling. This implies that investments at the class level are more feasible to improve listening skills and might partly compensate negative influences at the student level. Therefore, the present research synthesis provides directions as to how teachers might structure their listening courses to improve students' listening skills. The following teaching practices could be integrated into listening courses. First, students will remember more facts of auditory texts when they receive instruction in the specific structure of the text type (i.e. narrative or expository strategy instruction). Second, students' listening skills can be improved through applying visual techniques during listening training, such as telling stories supported by illustration (Oduolowu \& Oluwakemi, 2014) or asking students to paint a picture of the main features in their mind (Center et al., 1999). Third, listening strategy instruction affects listening skills positively. For example, teaching students different listening strategies such as listening for a purpose or predicting what could happen will improve their listening skills (Aarnoutse et al., 1998). Finally, listening skills can be improved through integrating listening activities into the entire curriculum and to combine listening activities with speaking, reading or writing activities. When teachers give students the opportunity to practice listening throughout the day instead of teaching listening solely in a separated course, students will become better listeners (Bilican et al., 2012).

In addition, this review provides evidence for the importance of adequate listening conditions in classrooms. Different studies showed that poor interior acoustics and background noise cause attention loss and exacerbate listening difficulties (e.g. Dockrell \& Shield, 2006), while systems improving the learning environment, such as sound system improvements, positively influence students' listening skills. In this respect, the findings are in line with other research indicating the significance of classroom design and classroom equipment on students' learning outcomes (e.g. Barrett, Zhang, Moffat, \& Kobbacy, 2013). Therefore, reducing class sizes and/or investing in sound systems by improving the sound environment in the classroom will positively influence students' listening performance, especially in classrooms with a high percentage of special needs students (McSporran et al., 1997).

\subsection{Recommendations for future research}


Notwithstanding the identification of some important correlates and the recommendations for further listening practice; future research in the regular primary school context is necessary to uncover unexplored correlates and to fine-tune our knowledge of listening education. Specifically, studies showing the relationship between school input or processes and students' listening skills were not found.

Moreover, as long-term studies were lacking in this review, different listening interventions (e.g. explicit listening strategy instruction or specific text type instruction) should be repeated in longitudinal research to explore whether or not the results persist over a longer period of time and to measure learning gain. Next to longitudinal research, multilevel listening research is also applied. Research that has investigated the impact of certain factors on listening skills appears to have been mostly conducted from a single-level perspective. However, such educational research should be multilevel in nature as students are nested in classrooms and classrooms are nested in schools (Creemers \& Kyriakides, 2010). Correlates operated at different levels (student, class or school level) and were expected to interact across levels to predict students' listening skills. Ignoring variation between these levels may therefore lead to a deficient evaluation of listening skills.

To conclude, this systematic review is relevant as it illustrates how listening education could be improved and by identifying different important correlates of listening skills. Nonetheless, further listening research in the primary school context is necessary to find unexplored correlates and to extend our knowledge in the field of effective listening education.

\section{Acknowledgement}

This work has been supported by the FWO.

\section{References}

Aarnoutse, C. A. J., van den Bos, K. P., \& Brand-Gruwel, S. (1998). Effects of listening comprehension training on listening and reading. Journal of Special Education, 32, 115-126. doi: $10.1177 / 002246699803200206$

Acat, M. B., Demiral, H., \& Kaya, M. F. (2016). Measuring listening comprehension skills of 5th grade school students with the help of web based system 1. International Journal of Instruction, 9(1), 211-224. doi: 10.12973/iji.2016.9116a

Adelmann, K. (2012) The Art of Listening in an Educational Perspective: Listening reception in the mother tongue. Education Inquiry, 3(4), 513-534. doi: 10.3402/edui.v3i4.22051

Arnold, P., \& Canning, D. (1999). “Does classroom amplification aid comprehension?” British Journal of Audiology, 33(3), 171-178. doi: 10.3109/03005369909090096

Barr, L., Dittmar, M., Roberts, E., \& Sheraden, M. (2002). Enhancing student achievement through the improvement of listening skills. ERIC document Reproduction Service No ED465999. 
Barrett, P., Zhang, Y., Moffat, J., \& Kobbacy, K. (2013). A holistic, multi-level analysis identifying the impact of classroom design on pupils' learning. Building and Environment, 59, 678-689. doi: 10.1016/j.buildenv.2012.09.016

Beall, L. M, Rosier-Gill, J., Tate, J., \& Matten, A. (2008). State of the Context: Listening Education. The International Journal of Listening, 22(2), 123-32. doi: 10.1080/10904010802174826

Behrens T. (2010). Keep it natural. Hearing Review, 17(11), 32-36.

Below, J. L., Skinner, C. H., Fearrington, J. Y., \& Sorrell, C. A. (2010). Gender differences in early literacy: Analysis of kindergarten through fifth-grade dynamic indicators of basic early literacy probes. School Psychology Review, 39, 240-257.

Bergen, E., Zuijen T., Bishop D., \& Jong P. F. (2017). Why are home literacy environment and children's reading skills associated? What parental skills reveal. Reading Research Quarterly, 52(2), 147-160. doi: 10.1002/rrq.160

Bilican, S., Kutlu, O., \& Yildirim, O. (2012). The Factors that predict the frequency of activities developing students' listening comprehension skills. Social and Behavioral Sciences, 46, 52195224. doi: 10.1016/j.sbspro.2012.06.413

Bommelje, R., Houston, J. M., \& Smither, R. (2003). Personality characteristics of effective listening: A five factor perspective. International Journal of Listening, 17, 32- 46. doi: 10.1080/10904018.2003.10499054

Bradley, R. H., \& Corwyn, R. F. (2002). Socioeconomic status and child development. Annual Review of Psychology, 53, 371-399. doi: 10.1146/annurev.psych.53.100901.135233

Brownell, J. (1994). Teaching Listening: Some Thoughts on Behavioural Approaches. Business Communication Quarterly, 57(4), 19-24. doi: 10.1177/ 108056999405700404

Brownell, J. (2006). Listening: Attitudes, principles, and skills ( ${ }^{\mathrm{rd}} \mathrm{ed}$.). Boston: Allyn and Bacon.

Brownell, J. (2012). Listening: Attitudes, principles, and skills ( $5^{\text {th }}$ ed.). New York: Pearson.

Cain, K. \& Bignell, S. (2014). Reading and listening comprehension and their relation to inattention and hyperactivity. British journal of educational psychology, 84(1). doi: org/10.1111/bjep.12009

Canpolat, M., Kuzu, S., Yıldırım, B., \& Canpolat, S. (2015). Active listening strategies of academically successful university students. Eurasian Journal of Educational Research, 60,163-180. doi: 10.14689/ejer.2015.60.10

Center, Y., Freeman, L., Robertson, G., \& Outhred, L. (1999). The effect of visual imagery training on the reading and listening comprehension of low listening comprehenders in year 2. Journal of Research in Reading, 22, 241-256. doi: 10.1111/1467-9817.00088

Cowan, N. (2008). What are the differences between long-term, and short-term, and working memory? Progress in brain research, 169(323-38), 323-338. doi: 10.1016/S0079-6123(07)00020-9

Creemers, B., \& Kyriakides, L. (2010). School Factors Explaining Achievement on Cognitive and Affective Outcomes: Establishing a Dynamic Model of Educational Effectiveness. Scandinavian Journal of Educational Research, 54(3), 263-294. doi: $10.1080 / 00313831003764529$

Crosskey, L., \& Vance, M. (2011). Training teachers to support pupils' listening in class: An evaluation using pupil questionnaires. Child Language Teaching and Therapy, 27(2), 165-182. doi: 10.1177/0265659010397249

De Smedt, F., Merchie, E., Bardense, M., Rosseel, Y., De Naeghel, J., \& Van Keer (2017). Cognitive and motivational key factors of late primary students' writing performance. Reading Research Quarterly, $O(0)$, 1-24. doi: 10.1002/rrq.193

Diakidoy, I. N. (2014). The effects of familiarization with oral expository text on listening and reading comprehension levels. Reading Psychology, 35(7), 622- $643 . \quad$ doi: $10.1080 / 02702711.2013 .790327$ 
Dickinson, D. K., McCabe, A., \& Sprague, K. (2003). Teacher rating of oral language and literacy (TROLL); individualizing early literacy instruction with a standards-based rating tool. The Reading Teacher, 56(6), 554-564.

Dockrell, J. E., \& Shield, B. M. (2006). Acoustical barriers in classrooms: The impact of noise on performance in the classroom. British Educational Research Journal, 32, 509- 525. doi: 10.1080/01411920600635494

Florit, E., Roch, M., \& Levorato, M. C. (2011). Listening text comprehension of explicit and implicit information in preschoolers: the role of verbal and inferential skills. Discourse Processes, 48, 119-138. doi: 10.1080/0163853X.2010.494244

Florit, E., Roch, M., \& Levorato, M. C. (2013). The relationship between listening comprehension of tekst and sentences in preschoolers: Specific or mediated by lower and higher level components? Applied Psycholinguistics, 34, 395-415. doi: 10.1017/S0142716411000749

Hedges, L. V., \& Olkin, I. (1985). Statistical methods for meta-analysis. San Diego, CA: Academic Press.

Hopkins, D., Stringfield, S., Harries, A., Stoll, L., \& Mackay, T. (2014) School and System Improvement: A state of the art review. School Effectiveness and School Improvement, 24(3), 257-281. doi: 10.1080/09243453.2014.885452

Hopper, J. (2007). An exploratory essay on listening instruction in the K-12 curriculum. International Journal of Listening, 12, 81-105.

Howard, C. S., Munro, K. J., \& Plack, C. J. (2010). Listening effort at signal-to-noise ratios that are typical of the school classroom. International Journal Audiology, 49, 928 -932. doi: $10.3109 / 14992027.2010 .520036$

Hulme, C., \& Snowling, M.J. (2009). Developmental Disorders of Language, Learning and Cognition. Oxford: Wiley-Blackwell.

Imhof, M. (2008). What have you listened to in school today? International Journal of Listening, 22, 112. doi: 10.1080/10904010701802121

Iwankovitsch, R. (2001). The Importance of Listening. Language Arts Journal of Michigan, 17(2), 5-6. doi: $10.9707 / 2168-149 X .1314$

Jalongo, M.R. (1996). Teaching young children to become better listeners. Young Children, 51(2), 2126.

Jalongo, M. R. (2008). Learning to listen, listening to learn. Washington, D.C.: NAEYC.

Janusik, L. (2002). Teaching Listening: What Do We Do? What Should We Do? International Journal of Listening, 16(1), 5-39. doi.10.1080/10904018.2002.10499047

Janusik, L. (2007) Building listening theory: the validation of the conversational listening span. Communication Studies, 58, 139-56. doi: 10.1080/10510970701341089

Janusik, L. (2010). Listening pedagogy: Where do we go from here? In A. D. Wolvin (Ed.), Listening and human communication in the 21st century (p. 193-223). Oxford: Wiley- Blackwell. doi: 10.1002/9781444314908.ch9

Janusik, L. A. \& Wolvin, A. D. (2002). Listening treatment in the basic communication course text. In D. Sellnow (Ed.), Basic communication course annual, 14, 164-210.

Johnson, D. I., \& Long, K. M. (2007). Student listening gains in the basic communication course: A comparison of self-report and performance-based competence measures. International Journal of Listening, 21, 92-101. doi: 10.1080/10904010701301990

Just, M. A., \& Carpenter, P. A. (1992). A capacity theory of comprehension: Individual differences in working memory. Psychological Review, 98, 122-149.

Kahneman, D. (1973). Attention and Effort. Englewood Cliffs. NJ: Prentice-Hall. 
Kieffer, M. J. (2012). Before and after third grade: longitudinal evidence for the shifting role of socioeconomic status in reading growth. Reading and Writing, 25, 1725-1746. doi: 10.1007/s11145-011-9339-2.

Kim, Y.-S. (2016). Direct and mediated effects of language and cognitive skills on comprehension of oral narrative texts (listening comprehension) for children. Journal of Experimental Child Psychology, 141, 101-120. doi: 10.1016/j.jecp.2015.08.003

Kim, Y.-S., \& Phillips, B. (2014). Cognitive correlates of listening comprehension. Reading and Research Quarterly, 49, 269-281. doi: 10.1002/rrq.74

Kim, Y.-S., Puranik, C. S., \& Otaiba, S. Al. (2015). Developmental Trajectories of Writing Skills in First Grade: Examining the Effects of SES and Language and/or Speech Impairments. The Elementary School Journal, 115(4), 593-613. doi:10.1086/681971

Klatte, M., Lachmann, T., \& Meis, M. (2010). Effects of noise and reverberation on speech perception and listening comprehension of children and adults in a classroom-like setting. Noise Health Noise, Mem. Learn. 12, 270-282. doi: 10.4103/1463-1741.70506

Kraemer, L., McCabe, P., \& Sinatra, R. (2012). The Effects of Read-Alouds of Expository Test on First Graders' Listening Comprehension and Book Choice. Literacy Research and Instruction, 512, 165-178. doi: 10.1080/19388071.2011.557471

Kutlu, Ö., \& Aslanoğlu, A. E. (2009). Factors Affecting the listening skill. Procedia Social and Behavioral Sciences, 1, 2013-2022. doi: 10.1016/j.sbspro.2009.01.354

Lau, K-L. (2017). Strategy Use, Listening Problems, and Motivation of High- and Low-Proficiency Chinese Listeners. Journal of Educational Research, 110(5), 503-514. doi: 10.1080/00220671.2015.1134421

Lehto, J. E., \& Antilla, M. (2003). Listening comprehension in primary level grades two, four and six. Scandinavian Journal of Educational Research, 47, 133-143.

Li, Cheng, \& Kirby (2012). Phonological Awareness and Listening Comprehension Among Chinese English- Immersion Students. International Education, 41(2).

Lin, S. W., Liu, Y., Chen, S.-F., Wang, J.-R., \& Kao, H.-L. (2014). Development of a computer-based measure of listening comprehension of science talk. International Journal of Science and Mathematics Education. Advance online publication. doi:10.1007/s10763-014-9559-4.

Loftus, G. R., \& Loftus, E. F. (1976). Human memory: the processing of information. Hillsdale. NJ: Eribaum.

Lynn, R., \& Mikk, J. (2009). Sex Differences in Reading Achievement. Trames, 13(1), 3-13. doi: 10.3176/tr.2009.1.01

Marley, S. C., \& Szabo, Z. (2010). Improving children's listening comprehension with a manipulation strategy. Journal of Educational Research, 103(4), 227-238. doi: 10.1080/00220670903383036

Mayer, R. E. (2001). Multimedia learning. New York: Cambridge University Press.

McInnes, A., Humphries, T., Hogg-Johnson, S., \& Tannock, R. (2003). Listening Comprehension and Working Memory Are Impaired in Attention-Deficit Hyperactivity Disorder Irrespective of Language Impairment. Journal of Abnormal child Psychology, 31(4), 427-443. doi: 00910627/03/0800-0427/0

McKenzie, N. J., \& Clark, A. J. (1995). The all-in-one concept: How much must listening research includes? International Journal of listening, 9, 29-43. doi: 10.1080/10904018.1995.10499140

McSporran, E., Butterworth, Y., \& Rowson, V. J. (1997). Sound field amplification and listening behaviour in the classroom. British Educational Research Journal, 23(1), 81-92. doi: 10.1080/0141192970230107

Moher, D. A., Liberati, J., Tetzlaff, \& Altman, D. G. (2010). Preferred reporting items for systematic reviews and meta-analyses: the PRISMA statement. International Journal of Surgery, 89, 336341. doi: 10.1136/bmj.b2535 
Oduolowu, E. O., \& Oluwakemi, A. E. (2014). Effect of storytelling on listening skills of primary one Pupil in Ibadan North Local Government area of Oyo State, Nigeria. International Journal of Humanities and Social Science, 4(9), 100-107.

Osada, N. (2004). Listening Comprehension Research: A Brief Review of the Last Thirty Years. Japan.

Owca, S., Pawlak, E., \& Pronobis, M. (2003). Improving student academic success through the promotion of listening skills. Chicago, IL: Saint Xavier University. ED 478233.

Palardy, G.J., \& Rumberger, R.W. (2008). Teacher effectiveness in first grade: The importance of background qualifications, attitudes, and instructional practices for student learning. Educational Evaluation and Policy Analysis, 30(2), 111-140. doi: 10.3102/0162373708317680

Paris, A. H., \& Paris, S. G. (2016). Teaching Narrative Comprehension Strategies to First Graders. Cognition and Instruction, 25(1), 1-44. doi: 10.1080/07370000709336701

Potocki, A., Ecalle, J., \& Magnan, A. (2013). Narrative comprehension skills in 5- year-old children: Correlational analysis and comprehender profiles. The Journal of Educational Research, 106, 14-26. doi: 10.1080/00220671.2012.667013

Pulsifer, M.B. (1996). The neuropsychology of mental retardation. Journal of the International Neuropsychological Society, 2(2), 159-176. doi: 10.1017/S1355617700001016P

Sandall, N., Schramm, K., \& Seibert, A. (2003). Improving Skills through the Use of Children's Literature. ERIC document Reproduction Service No ED482022.

Scheerens, J. (1992). Effective schooling. Research, theory and practice. London: Cassell.

Scheerens, J. (2016). Educational Effectiveness and Ineffectiveness. A Critical Review of the Knowledge Base. Dordrecht: Springer.

Shin, Y., \& Raudenbush, S. W. (2011). The causal effect of class size on academic achievement. Journal of Educational and Behavioral Statistics, 36(2), 154-185. doi: 10.3102/1076998610388632.

Stevens, R.J., Van Meter, P., \& Warcholak, N.D. (2010). The effects of explicitly teaching story structure to primary grade children. Journal of Literacy Research, 42(2), 159-198. doi: 10.1080/10862961003796173.

Sohr-Preston, S. L., Scaramella, L. V., Martin, M. J., Neppl, T. K., Ontai, L., \& Conger, R. (2013). Parental socioeconomic status, communication, and children's vocabulary development: A third-generation test of the family investment model. Child Development, 84, 1046-1062. doi:10.1111/cdev.12023

Swanson, C. H. (1997). Who's listening in the classroom? A research paradigm. ERIC Document Reproduction Service No. ED 407659.

Sweetow, R.W., \& Sabes, J.H. (2006). The need for and development of an adaptive listening and communication enhancement (LACE) program. Journal of the American Academy of Audiology, 17(8), 538-58. doi: /10.3766/jaaa.17.8.2

Tighe, E. L., Spencer, M., \& Schatschneider, C. (2015). Investigating predictors of listening comprehension in third, seventh, and tenth grade students: A dominance analysis approach. Reading Psychology, 36(8), 700-740. doi: 10.1080/02702711.2014.963270

Tok, Ş., \& Mazi, A. (2015) The effect of Stories for Thinking on reading and listening comprehension: a case study in Turkey. Research in Education, 93(1), 1-18. doi: 10.7227/RIE.0006

Vandergrift, L., (1997). The strategies of second language (French) listeners. Foreign Language annals, 30(3), 387-409. doi: 10.1111/j.1944-9720.1997.tb02362.x

Verlaan, W., Pearce, D. L., \& Zeng, G. (2017). Revisiting Sticht: The Changing Nature of the Relationship Between Listening Comprehension and Reading Comprehension Among Upper Elementary and Middle School Students Over the Last 50 Years. Literacy Research and Instruction, 56(2), 176-197. doi: 10.1080/19388071.2016.1275070

Witkin, B. R. (1990). Listening theory and research: The state of the art. Journal of the International Listening Association, 4, 7-32. doi: 10.1207/s1932586xij10401_3 
Witkin, B. R., \& Trochim, W. K. (1997). Toward a Synthesis of Listening Constructs: A Concept Map Analysis. International Journal of Listening, 11(1), 69-87. doi: 10.1207/s1932586xij11101_5

Wolfgramm, C, Suter, N., \& Göksel, E. (2016). Examining the Role of Concentration, Vocabulary and Self-concept in Listening and Reading Comprehension. International Journal of Listening, 30 (1-2), 25-46. doi: 10.1080/10904018.2015.1065746

Wolvin, A., \& Coakley, C. G. (2000). Listening education in the 21 st Century. International Journal of Listening, 14, 143-152. doi: 10.1080/10904018.2000.10499040

Wolvin, A. D. (2010). Listening engagement: Intersecting theoretical perspectives. In A. D. Wolvin (Ed.), Listening and human communication in the 21st century (pp. 7-30). Oxford: Blackwell. doi: $10.1002 / 9781444314908 . c h 1$

Xiaoxian, G., \& Yan, J. (2010). Interactive listening: Construct definition and operationalization in tests of English as a foreign language. Chinese Journal of Applied Linguistics, 33(6), 16-39.

Yildiz, M., Yildirim, K., Ates, S., Rasinski, T., Fitzgerald, S \& Zimmerman, B. (2014). The Relationship Between Reading Fluency and Reading Comprehension in Fifth-Grade Turkish Students. International Journal of School \& Educational Psychology, 2(1), 35-44, doi: 10.1080/21683603.2013.854187 


\section{Appendix}

Appendix A

Descriptive information of the studies on the class level: subcategory teacher practice

\begin{tabular}{|c|c|c|c|c|c|c|c|c|c|c|c|c|c|}
\hline Nr. & Authors & $\begin{array}{l}\text { Country } \\
\end{array}$ & $\begin{array}{l}\text { Grade: Sample } \\
\text { size }\end{array}$ & $\begin{array}{l}\text { Methodolog } \\
\mathrm{y} \text { (type of } \\
\text { analysis) }\end{array}$ & $\begin{array}{l}\text { Sample } \\
\text { selection }\end{array}$ & Design & $\begin{array}{l}\begin{array}{l}\text { Groups } \\
\text { (experiment: } \\
\text { control) }\end{array} \\
\end{array}$ & Duration & $\begin{array}{l}\text { Level of independent variables } \\
\text { according to the model of } \\
\text { Palardy and Rumberger }\end{array}$ & Intervention & Listening test & $\begin{array}{l}\text { Labeling listening skills } \\
\text { according to the HURIER } \\
\text { model }\end{array}$ & Study outcomes \\
\hline 1 & $\begin{array}{l}\text { Aarnoutse, } \\
\text { van den Bos } \\
\& \text { Brand- } \\
\text { Gruwel, } \\
1998\end{array}$ & $\begin{array}{l}\text { The } \\
\text { Netherlan } \\
\text { ds }\end{array}$ & $\begin{array}{l}4^{\text {th }}-6^{\text {th }} \text { grade } \\
(\mathrm{n}=169)\end{array}$ & $\begin{array}{l}\text { Quantitative } \\
\text { (ANOVA) }\end{array}$ & $\begin{array}{l}\text { Poor listening } \\
\text { and reading } \\
\text { students }\end{array}$ & $\begin{array}{l}\text { Experimental: pre- } \\
\text { test post-test retention } \\
\text { test control group } \\
\text { design (randomly } \\
\text { assigned) }\end{array}$ & $\begin{array}{l}\text { Ex }= \\
\text { listening } \\
\text { strategy } \\
\text { training } \\
\text { Co }=\text { no } \\
\text { interventi } \\
\text { on }\end{array}$ & $\begin{array}{l}20 \\
\text { lessons of } \\
30 \\
\text { minutes }\end{array}$ & $\begin{array}{l}\text { Specific practices Training in } \\
\text { four listening strategies: } \\
\text { clarifying, questioning, } \\
\text { summarizing and predicting }\end{array}$ & $\begin{array}{l}\text { After listening to a text a group } \\
\text { executes one or more strategies. } \\
\text { E.g. the discussion leader } \\
\text { explains difficult words } \\
\text { (understanding) or predicts the } \\
\text { future content of a text } \\
\text { (interpreting) and asks the others } \\
\text { what they think about it. }\end{array}$ & $\begin{array}{l}\text { *The Listening Comprehension } \\
\text { Test (stories, conversations, } \\
\text { expository texts) with multiple } \\
\text { choice questions at word, } \\
\text { sentence and text levels } \\
\text { *The Strategic Listening Test to } \\
\text { measure to apply the strategies }\end{array}$ & $\begin{array}{l}\text { Focuses on understanding } \\
\text { (e.g. defining difficult } \\
\text { words) and interpreting } \\
\text { (e.g. predicting the future } \\
\text { content of a text) }\end{array}$ & $\begin{array}{l}\text { Significant positive effect of } \\
\text { listening strategy training, } \\
\text { maintained on posttest and } \\
\text { retention test }(+*)(p<.05)\end{array}$ \\
\hline 2 & $\begin{array}{l}\text { Bilican, } \\
\text { Kutlu \& } \\
\text { Yildirim, } \\
2012\end{array}$ & Turkey & $\begin{array}{l}5^{\text {th }} \text { grade } \\
(\mathrm{n}=281)\end{array}$ & $\begin{array}{l}\text { Quantitative } \\
\text { (Multiple } \\
\text { regression) }\end{array}$ & I & Cross-sectional & 1 & 1 & $\begin{array}{l}\text { Instructional modalities: } \\
\text { Considering the activities that } \\
\text { develop listening comprehension }\end{array}$ & 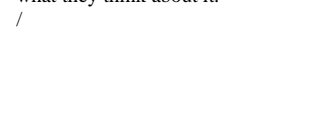 & $\begin{array}{l}\text { *Listening Comprehension } \\
\text { Activities Test (Likert type scale) } \\
\text { *Students Information } \\
\text { Questionnaire }\end{array}$ & $\begin{array}{l}\text { Focuses mainly on hearing } \\
\text { (i.e. using materials such as } \\
\text { radio or mp3) }\end{array}$ & $\begin{array}{l}\text { Significant positive effect of } \\
\text { writing summary, computer } \\
\text { usage, doing homework, radio } \\
\text { listening out of school and free } \\
\text { reading time }\left(+^{*}\right)(\mathrm{p}<.01)\end{array}$ \\
\hline 3 & $\begin{array}{l}\text { Center, } \\
\text { Freeman, } \\
\text { Roberston } \\
\text { \& Outhred, } \\
1999\end{array}$ & $\begin{array}{l}\text { United } \\
\text { States }\end{array}$ & $\begin{array}{l}2^{\text {nd }} \text { grade } \\
(\mathrm{n}=66)\end{array}$ & $\begin{array}{l}\text { Quantitative } \\
\text { (Univariate } \\
\text { analyses of } \\
\text { covariance) }\end{array}$ & $\begin{array}{l}\text { Poor listening } \\
\text { comprehension } \\
\text { students }\end{array}$ & $\begin{array}{l}\text { Experimental: pre- } \\
\text { test post-test control } \\
\text { group design } \\
\text { (matched pairs } \\
\text { randomly assigned to } \\
\text { groups) }\end{array}$ & $\begin{array}{l}\text { Ex }= \\
\text { instructio } \\
\text { n with } \\
\text { visual } \\
\text { imagery } \\
\text { Co }= \\
\text { instructio } \\
\text { n without } \\
\text { visual } \\
\text { imagery }\end{array}$ & $\begin{array}{l}12 \\
\text { lessons of } \\
20 \\
\text { minutes } \\
\text { for a } \\
\text { period of } \\
\text { four } \\
\text { weeks }\end{array}$ & $\begin{array}{l}\text { Specific practices: Training in } \\
\text { visual imagery and visualization } \\
\text { techniques while listening }\end{array}$ & $\begin{array}{l}\text { Lessons consisted of different } \\
\text { components: } \\
\text { Discussion of one aspect e.g. } \\
\text { identifying characters } \\
\text { (understanding) } \\
\text { Facilitating comprehension by } \\
\text { introducing the prepared passage } \\
\text { or story, activating prior } \\
\text { knowledge (interpreting) } \\
\text { The experimental group was } \\
\text { asked to try to visualize the main } \\
\text { features. }\end{array}$ & $\begin{array}{l}\text { *Reading Accuracy and Reading } \\
\text { Comprehension subtest of the } \\
\text { Neale Analysis } \\
\text { *Adapted listening } \\
\text { comprehension } \\
\text { *Story Event Structure }\end{array}$ & $\begin{array}{l}\text { Focuses mainly on } \\
\text { interpreting (i.e. students } \\
\text { have to relate two stories to } \\
\text { each other) and } \\
\text { remembering (i.e. students } \\
\text { had to tell a story which } \\
\text { was audiotataped and } \\
\text { transcribed) }\end{array}$ & $\begin{array}{l}\text { Significant positive relationship } \\
\text { with explicit instruction in visual } \\
\text { imagery (+*) Byrne Listening } \\
\text { Comprehension: (p=.018) } \\
\text { Neale Listening Comprehension } \\
\text { (p= }=099 \text { ) }\end{array}$ \\
\hline 4 & $\begin{array}{l}\text { Diakidoy, } \\
2014\end{array}$ & Cyprus & $\begin{array}{l}2^{\text {nd }} \text { grade } \\
(\mathrm{n}=203)\end{array}$ & $\begin{array}{l}\text { Quantitative } \\
\text { (Hierarchical } \\
\text { Regression } \\
\text { analyses) }\end{array}$ & 1 & $\begin{array}{l}\text { Experimental: pre- } \\
\text { test post-test control } \\
\text { group design } \\
\text { (randomly assigned) }\end{array}$ & $\begin{array}{l}\text { Ex= } \\
\text { familiariz } \\
\text { ation with } \\
\text { text type } \\
\text { Co = no } \\
\text { interventi } \\
\text { on }\end{array}$ & $\begin{array}{l}18 \\
\text { lessons of } \\
40 \\
\text { minutes } \\
\text { for a } \\
\text { period of } \\
9 \text { weeks }\end{array}$ & $\begin{array}{l}\text { Specific practices: } \\
\text { Familiarization with oral } \\
\text { expository text types }\end{array}$ & $\begin{array}{l}\text { Familiarization phase: The } \\
\text { teachers were given a packet } \\
\text { containing the selected } \\
\text { expository texts and the } \\
\text { corresponding comprehension } \\
\text { questions. Teachers must read } \\
\text { aloud a text in class and pose } \\
\text { comprehension questions } \\
\text { (understanding and interpreting) } \\
\text { that followed in a whole class- } \\
\text { discussion context. }\end{array}$ & $\begin{array}{l}\text { *Sentence verification task: } \\
\text { listening to an expository and } \\
\text { comprehension text - literal and } \\
\text { inferential statements followed } \\
\text { by a yes/no option }\end{array}$ & $\begin{array}{l}\text { Focuses on understanding } \\
\text { (literal statements e.g. } \\
\text { single idea units) and } \\
\text { interpreting (inferential } \\
\text { statements e.g. } \\
\text { comparison/contrast } \\
\text { relationships between text } \\
\text { idea units) }\end{array}$ & $\begin{array}{l}\text { No significicant effect of text } \\
\text { familiarization on listening } \\
\text { comprehension (either expository } \\
\text { or narrative) (p=.74) }\end{array}$ \\
\hline 5 & $\begin{array}{l}\text { Kraemer, } \\
\text { McCabe \& } \\
\text { Sinatra, } \\
2008\end{array}$ & $\begin{array}{l}\text { New } \\
\text { York }\end{array}$ & $\begin{array}{l}1^{\text {st }} \text { grade } \\
(\mathrm{n}=77)\end{array}$ & $\begin{array}{l}\text { Quantitative } \\
\text { (MANOVA) }\end{array}$ & I & $\begin{array}{l}\text { Experimental: pre- } \\
\text { test post-test control } \\
\text { group design (cluster } \\
\text { sampling, randomly } \\
\text { assigned) }\end{array}$ & $\begin{array}{l}\text { Ex }= \\
\text { read- } \\
\text { aloud } \\
\text { procedure } \\
\text { Co }=\text { no } \\
\text { visits or } \\
\text { reading }\end{array}$ & $\begin{array}{l}12 \\
\text { sessions } \\
\text { for a } \\
\text { period of } \\
4 \text { weeks }\end{array}$ & $\begin{array}{l}\text { Specific practices: Read-aloud } \\
\text { procedure using expositiory } \\
\text { instruction material. } 12 \text { first- } \\
\text { grade EI EI texts t(ten books and two } \\
\text { articles) were used. }\end{array}$ & $\begin{array}{l}\text { Read-aloud procedure: } \\
\text { Researcher read one EI book or } \\
\text { article per visit (Hearing). Each } \\
\text { session began with a discussion } \\
\text { about the topic of text. During } \\
\text { the read-aloud, there was time for } \\
\text { occasional comments and } \\
\text { questions. After each read-aloud } \\
\text { the researcher asked the class to } \\
\text { hare new things that they learned } \\
\text { (Understanding). }\end{array}$ & $\begin{array}{l}\text { * Passages from the Qualitative } \\
\text { Reading Inventory-3 }\end{array}$ & $\begin{array}{l}\text { Focuses on understanding } \\
\text { (e.g. answers clearly stated } \\
\text { in the text) and interpreting } \\
\text { (make an inference) }\end{array}$ & $\begin{array}{l}\text { Highly positive significant effect } \\
\text { of the read-aloud procedure on } \\
\text { expository listening } \\
\text { comprehension }(\mathrm{p}<.001)(+*)\end{array}$ \\
\hline
\end{tabular}


$6 \quad$ s

$\begin{array}{ll}\text { Marley \& } & \text { New } \\ \text { Szabo, } 2010 & \text { Mexico }\end{array}$

$\begin{array}{ll}\substack{\text { Kindergarten - } \\ \text { 1. grade } \\ \text { (n=76) }} & \text { Quantitative } \\ \text { (ANCOVA) }\end{array}$

Experimental: pre-
test post-test control
group design
(randomly assigned)

Ex $=$
stories
with
manipul
ion
Co $=$
stories
with

3 session
of 40

minutes

with

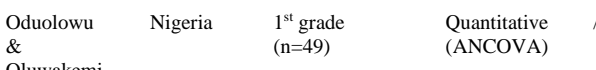

Oluwakem
2014

$\begin{array}{lll}8 & \text { Paris \& } & \text { United } \\ \text { Paris, 2007 } & \text { States }\end{array}$

$1^{\text {st }}$ grade
$(\mathrm{n}=123)$

Experimental: pre-

test post-test contro

technique and

randomly assigned

Ex $=$

$\mathrm{g}$ with 8 weeks

ns

storytelliti

g without
illustratio

$\mathrm{ns}$
$\mathrm{Ex}=$

Experimental: pre-

design (randomly

assigned

narrative
comprehe
nsion

strategy

training

interven

period of
5 weeks

aarrative strategy instruction:

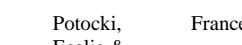

\begin{tabular}{|c|c|c|c|}
\hline $\begin{array}{l}\text { Potocki, } \\
\text { Ecalie \& } \\
\text { Magnan, }\end{array}$ & France & $\begin{array}{l}2^{\text {nd }} \text { grade } \\
(\mathrm{n}=258)\end{array}$ & $\begin{array}{l}\text { Quantitative } \\
\text { (ANOVA) }\end{array}$ \\
\hline
\end{tabular}

2013

10

$\begin{array}{llllll}\begin{array}{l}\text { Stevens, } \\ \text { Van Meter }\end{array} & \begin{array}{l}\text { United } \\ \text { States }\end{array} & \begin{array}{l}\text { Kindergarten } \\ \text { and 1 1t grade } \\ (\mathrm{n}=321)\end{array} & \begin{array}{l}\text { Quantitative } \\ \text { (MANOVA) }\end{array} & \begin{array}{l}\text { High poverty } \\ \text { schools }\end{array} & \begin{array}{l}\text { Experimental: pre- } \\ \text { test post-test control } \\ \text { group design }\end{array} \\ \text { Warcholak, } & & & & \text { (stratified random } \\ 2016 & & & & & \text { sampling) }\end{array}$

$\begin{array}{llll}\text { Experimental: pre- } & \text { Ex }=\text { CAI } & 20 & \text { Instructional modalities: Training } \\ \text { test post-test control } & \text { to assist } & \text { sessions } & \text { listening comprehension with a } \\ \text { cosprehe }\end{array}$ group retention test comprehe of 30 design (randomly
assigned)

$\mathrm{Co}=\mathrm{CA}$ encourag decodin

decoding
$\mathrm{Ex}=$
story

story structure $\quad$ one

$\begin{array}{ll}\text { reading } & \text { school } \\ \text { children's } & \text { year }(15 \\ \text { minutes }\end{array}$

cillire

literature
$\mathrm{Co}=$ no

$\mathrm{Co}=$ no
story
structure

during

hildren's

literature program (CAI)

for a
period of 5 weeks

For a Specific practices: Training the Specific practices: Training the
narrative structure through story Shut instruction (SSI). SS more guided practice that what normally occurs during implements different elements aloud, teacher asks questions about story structure of the story after reading)
Specific practices: Training with

-imagining)

\section{For a}

Specific practices: Training in
narrative comprehension strategy

Specific practices: Training

illustration (picture storybook)

Storytelling without illustration
Remembering (i.e. trained

identifying narrative text
structure (understanding) and

bolster inferences about traditional storybook reading (i.e. teachers told each of the thre weeks. During the sevort werk the pupils were asked to retell al the three stories)

Direct strategy comprehensi
instruction about narrative

elements and relations. They

taught children strategies for

psychological aspects of stories and making inferences

(interpreting)

* Assessing on free recall and 12 cued-recall items of story events (memory test): Students recorded.

$$
\text { e story was tape }
$$

LoCoTEx: a text comprehension training software program. The software practices on lit understanding) and inferential

Focuses on remembering (i.e. participants were
requested to recall as maly story events as they could administered 12 cued-recal
items)

Story Structure Instruction: who is the main character and dering information) and responding (e.g. teacher ast
students for responses).
*Battery of wordless narrative and expository comprehension
tasks (picture book) Children were asked to retell the story a according to the number and Comprehension was assessed by asking questions about five explicit and implicit text relations
${ }^{*}$ Listening Comprehension tasks "Listening Comprehension task assess L.C. and strategy use by

metacognitive questions

* Listening comprehensive tes using a short narrative with

Story structure measures with Tree and prompted recall abilities (i.e students were ased to retell the story read to them their responses were scored
Focuses on remembering (i.e. retelling the story),
understanding or literal

understanding (e.g.

character, problem),

interpreting of inferen

prediction, theme,

prediction, the
sequencing)

Focuses on understanding
(e.g. explicit information

(e.g. explicit information

and interpreting (e.g.
coherence inferences)

Focuses on rememberin (i.e. free recall) and

understanding (e.g.

location, main character,

problem solution)
Significant positive effect of physical manipulation followe *instructional period $1(\mathrm{p}<01)$ "instructional period 2 ( $\mathrm{p}<.01)$. participants recall of $62 \%$ and picture strategy participants'
recall of $47 \%$.

gnificant positive effect of storytelling with illustration $(+*)$ $(\mathrm{p}=.016)$

Significant positive effect of comprehension task in the experimental group $(+*)(p<.05)$

Significant positive effect of the computer assisted instruction Effect was non-significant after the first post-test (at the end of the intervention), but significant
after an interval of 11 months after the end of the intervention.

Significant positive effect of SSI on narrative comprehension
(significant higher free recall of details about the main character $p$ $=.002$ and problem solution $\mathrm{p}=$ .007) (+*)

(non-significant higher free recall off setting $\mathrm{p}=.018$ and attempted
solution $\mathrm{p}=5.31$

recall of details about the main character $\mathrm{p}=.000$, problem
solution $\mathrm{p}=.002$ and setting $\mathrm{p}=$ 
 $\begin{array}{lllll}\begin{array}{l}\text { control group design } \\ \text { (not randomly }\end{array} & \begin{array}{l}\text { thinking } \\ \mathrm{Co}=\end{array} & \begin{array}{l}\text { a period } \\ \text { of } 10\end{array} & \begin{array}{l}\text { stories for thinking }=\text { thinking } \\ \text { together about stories }\end{array} & \begin{array}{l}\text { facilitiorpeting (i.e. recognizing } \\ \text { on interpret }\end{array}\end{array}$ the theme step) and responding (i.e. the class was dividion
discussion groups)
title for the story, guess the end of the story) and neesponding (e.g. studen about the story, write a story about the theme)

Appendix B

Descriptive information of the studies on the class level: subcategory classroom features

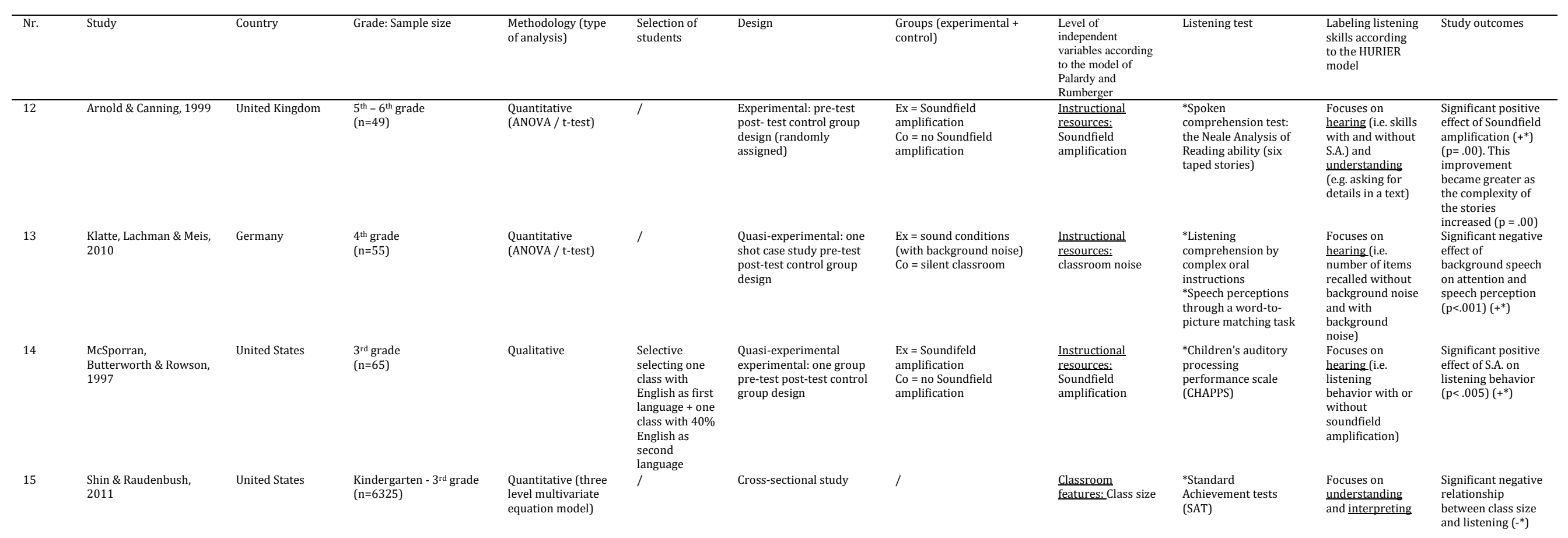


Appendix C

Descriptive information of the studies on the class level: subcategory teacher background characteristics

\begin{tabular}{|c|c|c|c|c|c|c|c|c|c|c|}
\hline $\mathrm{Nr}$. & Study & Country & Grade: Sample size & $\begin{array}{l}\text { Methodology (type of } \\
\text { analysis) }\end{array}$ & Duration & Design & $\begin{array}{l}\text { Level and description } \\
\text { of independent } \\
\text { variables }\end{array}$ & Intervention & Listening test & Study outcomes \\
\hline 16 & $\begin{array}{l}\text { Crosskey \& Vance, } \\
2011\end{array}$ & United States & $\begin{array}{l}3^{\text {rdd }} 6^{\text {th }} \text { grade } \\
(\mathrm{n}=27)\end{array}$ & $\begin{array}{l}\text { Quantitative (multiple } \\
\text { post-hoc analyses) }\end{array}$ & $\begin{array}{l}\text { Two sessions, } \\
\text { each lasting for } \\
90 \text { minutes }\end{array}$ & $\begin{array}{l}\text { Quasi-experimental: } \\
\text { Pre-test post-test } \\
\text { design with retention } \\
\text { test after three months }\end{array}$ & $\begin{array}{l}\text { Teacher background: } \\
\text { Teacher training } \\
\text { Package with a } \\
\text { selection of ideas } \\
\text { and strategies to } \\
\text { support listening in a } \\
\text { whole class group }\end{array}$ & $\begin{array}{l}\text { Communication Friendly } \\
\text { Environments package: } \\
\text { presenting information } \\
\text { about theoretical aspect } \\
\text { of listening including } \\
\text { attention (hearing), } \\
\text { processing information } \\
\text { (understanding) and } \\
\text { memory (remembering) }\end{array}$ & $\begin{array}{l}\text { *Questionnaire using } \\
\text { software (focus and } \\
\text { attention, processing of } \\
\text { the language to } \\
\text { understand, retention of } \\
\text { information and } \\
\text { instructions) }\end{array}$ & $\begin{array}{l}\text { Significant positive effect } \\
\text { of the listening training } \\
(+*)(p<.01)\end{array}$ \\
\hline
\end{tabular}


Appendix D

Descriptive information of the studies on the student level

\begin{tabular}{|c|c|c|c|c|c|c|c|c|c|c|}
\hline $\mathrm{Nr}$. & Study & $\begin{array}{l}\text { Count } \\
\text { ry }\end{array}$ & $\begin{array}{l}\text { Grade: Sample } \\
\text { size }\end{array}$ & $\begin{array}{l}\text { Methodology (type } \\
\text { of analysis) }\end{array}$ & $\begin{array}{l}\text { Selection } \\
\text { of } \\
\text { students }\end{array}$ & Design & $\begin{array}{l}\text { Level and description of } \\
\text { independent variables according to } \\
\text { the model of Palardy and } \\
\text { Rumberger }\end{array}$ & Listening test & $\begin{array}{l}\text { Labeling listening skills } \\
\text { according to the HURIER } \\
\text { model }\end{array}$ & Study outcomes \\
\hline 17 & Acat, Demiral \& Kaya, 2016 & $\begin{array}{l}\text { Turke } \\
\text { y }\end{array}$ & $\begin{array}{l}5^{\text {th }} \text { grade } \\
(\mathrm{n}=605)\end{array}$ & $\begin{array}{l}\text { Quantitative (T-test, } \\
\text { ANOVA, Turkey HSD } \\
\text { test) }\end{array}$ & / & $\begin{array}{l}\text { Descriptive: } \\
\text { cross-sectional }\end{array}$ & $\begin{array}{l}\text { Academic background: } \\
\text { Fanguage scores } \\
\text { Family background: } \\
\text { Eduction level of the } \\
\text { mother len level of } \\
\text { - Education level of the } \\
\text { father } \\
\text { - Household income } \\
\text { Music type }\end{array}$ & $\begin{array}{l}{ }^{*} \text { The Listening } \\
\text { Comprehension Test } \\
\text { *Web based listening } \\
\text { scale }\end{array}$ & $\begin{array}{l}\text { Focuses on } \\
\text { understanding and } \\
\text { interpreting }\end{array}$ & $\begin{array}{l}\text { Significant positive relationship with } \\
\text { Education level of the father } \\
(\mathrm{p}<.01) \\
\text { and the mother }\left(+^{*}\right)(\mathrm{p}<.01) \\
\text { Household income }(+*)(\mathrm{p}<.01) \\
-\quad \text { Language scores }\left(+^{*}\right)(\mathrm{p}<.05) \\
\quad \text { Favorite and mostly listened } \\
\text { music type (upbeat music) }\left(+^{*}\right) \\
(\mathrm{p}<.01)\end{array}$ \\
\hline 18 & Cain \& Bignell, 2014 & UK & $\begin{array}{l}\text { 7- to } 11 \text { - year- } \\
\text { olds }(\mathrm{n}=66)\end{array}$ & $\begin{array}{l}\text { Quantitative } \\
\text { (ANOVA) }\end{array}$ & $\begin{array}{l}\text { Children } \\
\text { at risks } \\
\text { of ADHD }\end{array}$ & $\begin{array}{l}\text { Descriptive: } \\
\text { cross-sectional }\end{array}$ & $\begin{array}{lc}\text { Academic background: } \\
\quad \text { Poor attention } \\
\text { High hyperactivity }\end{array}$ & ${ }^{*}$ NARA-2 & $\begin{array}{l}\text { Focuses on } \\
\text { understanding }\end{array}$ & $\begin{array}{l}\text { Significant negative relationship with } \\
\text { hyperactivity and poor attention } \\
(\mathrm{p}<.001)\left({ }^{*}\right)\end{array}$ \\
\hline 19 & Kim \& Philips, 2014 & $\begin{array}{l}\text { United } \\
\text { States } \\
\text { of } \\
\text { Ameri } \\
\text { ca }\end{array}$ & $\begin{array}{l}\text { Kindergarten } \\
\& 11^{\text {st grade }} \\
(\mathrm{n}=156)\end{array}$ & $\begin{array}{l}\text { Quantitative } \\
\text { (Structural Equation } \\
\text { Modeling) }\end{array}$ & $\begin{array}{l}\text { High- } \\
\text { poverty } \\
\text { public } \\
\text { schools }\end{array}$ & $\begin{array}{l}\text { Descriptive: } \\
\text { cross-sectional }\end{array}$ & \begin{tabular}{ll}
\multicolumn{2}{l}{ Academic factors } \\
\hdashline$\quad$ Vocabulary \\
$-\quad$ Comprehension \\
$\quad$ monitoring \\
$\quad$ Inhibitory control \\
Demographic factors \\
Age
\end{tabular} & $\begin{array}{l}{ }^{*} \text { Listening } \\
\text { Comprehension Scale } \\
\text { of the Oral and } \\
\text { Written Language } \\
\text { Scales } \\
\text { *Test of Narrative }^{\text {The }} \\
\text { Language }\end{array}$ & $\begin{array}{l}\text { Focuses on } \\
\text { understanding (e.g. } \\
\text { character-'s name) }\end{array}$ & $\begin{array}{l}\text { Significant positive relationship with: } \\
\quad \quad \text { Vocabulary (p<.001) } \\
\text { - ToM (p<.001) } \\
\quad \text { Comprehension monitoring } \\
\quad \text { (p<.001) } \\
\text { Inhibitory control ( }<<.001) \\
\text { Non-significant relationship with: } \\
\qquad \quad \text { Age (p=.97) }\end{array}$ \\
\hline 20 & Kutlu \& Aslanoğlu, 2009 & $\begin{array}{l}\text { Turke } \\
\mathrm{y}\end{array}$ & $\begin{array}{l}5^{\text {th grade }} \\
(\mathrm{n}=265)\end{array}$ & $\begin{array}{l}\text { Quantitative (Factor } \\
\text { analysis) }\end{array}$ & / & $\begin{array}{l}\text { Descriptive: } \\
\text { cross-sectional }\end{array}$ & $\begin{array}{ll}\text { Family background: } \\
& \text { Number of books at home } \\
\text { Time spent reading and } \\
& \text { listening at home } \\
\text { - } & \text { Material used in the } \\
& \text { classroom } \\
\text { - } & \text { Education level of parents } \\
& \text {... }\end{array}$ & $\begin{array}{l}\text { *A listening } \\
\text { comprehension test } \\
\text { (text + short-answer } \\
\text { questions) }\end{array}$ & $\begin{array}{l}\text { Focuses on } \\
\text { understanding (e.g. } \\
\text { finding explicit ideas), } \\
\text { interpreting (e.g. relating } \\
\text { the themes to personal } \\
\text { knowledge and } \\
\text { experience) and } \\
\text { evaluating (e.g. evaluate } \\
\text { the elements, content and } \\
\text { language of the text) }\end{array}$ & 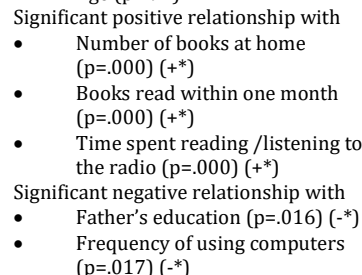 \\
\hline 21 & Lau, 2017 & China & $\begin{array}{l}7^{\text {th }} \text { and } 9^{\text {th }} \\
\text { grade } \\
\text { (n=2805) } \\
\text { Qualitative }= \\
24\end{array}$ & $\begin{array}{l}\text { Quantitative } \\
\text { (MANOVA) and } \\
\text { qualitative }\end{array}$ & 1 & $\begin{array}{l}\text { Descriptive: } \\
\text { cross-sectional } \\
\text { Qualitative: } \\
\text { retrospective } \\
\text { interviews with } \\
\text { coding criteria }\end{array}$ & \begin{tabular}{ll}
\multicolumn{2}{l}{ Listening motivation: } \\
& Intrinsic interest \\
& Listening importance
\end{tabular} & $\begin{array}{l}\text { *A Chinese-language } \\
\text { listening } \\
\text { comprehension test }\end{array}$ & $\begin{array}{l}\text { Focuses on } \\
\text { understanding (i.e. } \\
\text { identify information that } \\
\text { has been directly } \\
\text { mentioned), interpreting } \\
\text { (i.e. integrate different } \\
\text { info and implicit meaning } \\
\text { of the text) and evaluating } \\
\text { (i.e. making judgments } \\
\text { about the content of the } \\
\text { text) }\end{array}$ & 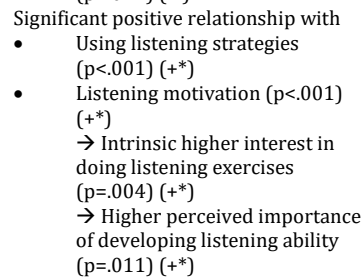 \\
\hline 22 & Lehto \& Antilla, 2003 & $\begin{array}{l}\text { Finlan } \\
\text { d }\end{array}$ & $\begin{array}{l}2^{\text {nd }}, 4^{\text {th }} \text { and } 6^{\text {th }} \\
\text { grade }(n=107)\end{array}$ & Quantitative & I & $\begin{array}{l}\text { Descriptive: } \\
\text { cross-sectional }\end{array}$ & \begin{tabular}{ll}
\multicolumn{2}{l}{ Demographic factors } \\
$-\quad$ & Gender \\
- & Age
\end{tabular} & $\begin{array}{l}\text { *Sentence verification } \\
\text { technique (narrative } \\
\text { and expository } \\
\text { passages) }\end{array}$ & $\begin{array}{l}\text { Focuses on remembering } \\
\text { (i.e. students hear a short } \\
\text { passage and afterwards } \\
\text { the pupil is given } \\
\text { sentences related to the } \\
\text { passage and have to judge } \\
\text { whether this is correct or } \\
\text { incorrect) }\end{array}$ & 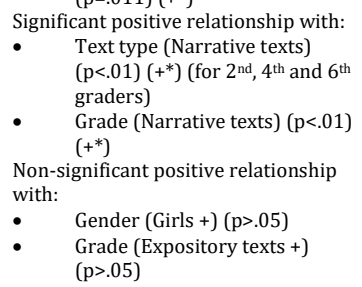 \\
\hline
\end{tabular}


Demographic factors

- Language

assessment for
listening

listening

coefrient (test)

Significant positive relationship with:

Complex sentence span

measure $\left(+^{*}\right)(p<.05)$

Non-significant relationship with:
$\quad \quad$ Backward digit span $(p>05)$

- Word span ( $\mathrm{p}>$.05)

Oduolowu \& Oluwakem

2014

Tighe, Spencer \&

Nigeri $\quad 1^{\text {st } g r}$

Unit

United $3^{\text {rd }} 7^{\text {th }}$ an

$\underset{\mathrm{n}=585)}{\text { grade }}$

Wolfgramm, Suter \& Göksel,

2016

$\begin{array}{ll}\text { Switze } & 6^{\text {th }} \text { grade } \\ \text { rland } & (\mathrm{n}=345)\end{array}$

\section{Quantitative
(ANCOVA)}

Quantitative (PCA) /

Quantitative

(Structural equatio
modeling)

$\operatorname{Kim}(2016)$ $\begin{array}{ll}\text { South } & 1^{\text {st grade }} \\ \text { Korea } & (\mathrm{n}=201)\end{array}$

Quantitative
(Structural equation modeling)
Quasi-

experimental:
Pre-test post-tes
control group

control grou
design

Descriptive:

coss-sectional

Descriptive:
cross-sectional

Demographic factors

$\begin{array}{ll}\text { - } & \text { Gender } \\ & \text { Cultural background }\end{array}$

Academic factors

Working memory

Verbal and
reasoning
Fluency

Academic factors

Concentration
Vocabulary
Working

Demographic factors

Family factors

Home language

Descriptive:
cross-sectional
Academic factors

- Working memory

- Attention
Vocabulary
*Morrow's 10-point

scale for retelling
analysis

*Florida

Comprehensive
Assessment Test

\section{*Listening}

comprehension test

Klassencockpit
HarmoS test)

* Oral listening

comprehension test
Focuses on remembering

(i.e. pu
stories

Focuses on remembering

nd understanding

Focuses on

understanding (e.g. What

word mean?)

Focuses on

understanding an
Significant positive relationship with:

Gender (Girls $\left.+^{*}\right)(\mathrm{p}=.001)$
$\quad$ Cultural background $\left(+^{*}\right)$ $(\mathrm{p}=.000)$

Significant positive relationship with: Verbal and nonverbal reasoning - $\quad$ Fluency $\left(+^{*}\right)(\mathrm{p}<05)$

- Working memory $\left(+^{*}\right)(\mathrm{p}<0.05)$

Significant positive relationship with:

- $\quad$ Concentration $\left(+^{*}\right)(\mathrm{p}=.02)$

Home language $(-*)(\mathrm{p}<.001)$

Non-significant relationship with:

Gender (Boys +$)(p=019)$

Working memory (-) (p=.18)

Academic self-concept $(-)$
$(p=.52)$
Significant positive relationship with

(p<.05) Working memory*

- Working memory
Attention ${ }^{*}$

Attention $*$
Vocabulary
G

Vocabulary*
Grammatical knowledge * 
